\title{
Economic Consequences of State Failure-Legal Capacity, Regulatory Activity, and Market Integration in Poland, 1505-1772
}

Mikotaj MaLinowsKi

\begin{abstract}
With use of innovative proxies and new annual data, I demonstrate that relatively high legal capacity and regulatory activity of the early-modern Polish parliament, the Seym, was positively associated with deeper domestic commodity market integration. Conversely, the lack of effective law-making, caused by the right of a single delegate to discontinue the Seym's sessions, fostered market fragmentation. This indicates that early parliamentary regimes required legal capacity to harmonize domestic institutions and reduce the transaction costs. The Polish case suggests a hypothesis that the pre-1800 "Little Divergence" between European parliamentary regimes could be explained by differences in their governments' capacities.
\end{abstract}

W

hat factors allowed certain regions of Europe to develop their market economies early on and what were the reasons for the relative stagnation of the less successful areas? Specifically, what was the role of the early-modern transition from feudalism to semi-centralised and relatively powerful territorial states in setting the stage for modern economic growth? Political institutions are argued to be crucial determinants of prosperity (e.g., Acemoglu and Robinson 2012). Many scholars identify the parliamentary form of governance and the rule-of-law as preconditions for the market economy (e.g., North and Weingast 1989). The "Little Divergence" in pre-1800 economic development between

The Journal of Economic History, Vol. 79, No. 3 (September 2019). This is an Open Access article, distributed under the terms of the Creative Commons Attribution license (http://creativecommons.org/licenses/by/4.0/), which permits unrestricted re-use, distribution, and reproduction in any medium, provided the original work is properly cited. All rights reserved. doi: 10.1017/S0022050719000330

Mikołaj Malinowski is Postdoctoral Research Fellow, Department of History and Art History at Utrecht University / Institute of Economic History at Humboldt University, Berlin / Department of Economic History at Lund University, Box 7083, 22007 Lund, Sweden. E-mail: mikolaj. malinowski@ekh.lu.se.

The article is a result of the Handelsbanken-sponsored research project P18-0050 titled "Parliaments and Prosperity. The Impact of State Capacity on Economic Growth in pre-1800 Europe" of which the author is the Principal Investigator. The author wishes to acknowledge the comments and contributions of Bob Allen, Christiaan van Bochove, Joerg Baten, Dan Bogart, Stephen Broadberry, Paweł Bukowski, Tracy Dennison, Kerstin Enflo, Leandro Prados de la Escosura, James Fenske, Ewout Frankema, Leigh Gardner, Erik Green, Jacek Kochanowicz, Michał Kopczyński, Markus Lampe, Steven Nafziger, Sheilagh Ogilvie, Mats Olsson, Nuno Palma, Şevket Pamuk, Maarten Prak, James Robinson, Eric Schneider, Paul Sharp, Max Shulze, Jacob Weisdorf, Nikolaus Wolf, Oliver Volckart, Tamas Vonyo, and Jan Luiten van Zanden. The author accepts responsibility for all remaining errors and omissions. 
England/Britain, the Netherlands, and the rest of Europe is often linked to the formation of territorial parliamentary regimes in the two successful countries (e.g., Van Zanden, Buringh, and Bosker 2012; Broadberry and Wallis 2017). The available GDP evidence suggests that both the British Glorious Revolution of 1688 and the Dutch Act of Abjuration of 1581 were followed by long periods of sustained economic growth. However, not all parliamentary regimes prospered. For example, the available GDP evidence shows that both the transition of Poland into a parliamentary republic in the sixteenth century (this will be discussed later in detail) as well as the change from absolutism to a parliamentary form of government in Sweden in 1718, were followed by protracted economic decline (Bolt and Van Zanden 2014; Malinowski and Van Zanden 2017). The fact that not all preindustrial parliamentary regimes succeeded economically demonstrates that the consolidation of power around a parliament is an insufficient condition for sustained economic growth.

Why did some pre-industrial parliamentary regimes prosper while others did not? According to Timothy Besley and Torsten Persson (2011), a state can promote prosperity only if it possesses (1) legal capacity denoting the authority and infrastructure to create and enforce the law and (2) fiscal capacity representing the means to finance its operations. With this study, I contribute to the growing literature on the role of centralisation and state capacity in promoting economic growth and market development before 1800 (Bonney 1995; O’Brien 2011; Chilosi, Schulze, and Volckart 2018; Dincecco and Katz 2016; Dimitruk 2018; Epstein 2001; Johnson and Koyama 2017). I complement the earlier studies that predominantly focused on fiscal capacity with an original study of the impact of legal capacity. Specifically, I analyse the role that the Polish Diet played in developing an integrated domestic commodity market.

Early modern Poland is uniquely suited to study the economic impact of the parliamentary regime. In the sixteenth century, Poland both limited the authority of the King and experienced, in relative terms, a golden age of political centralisation under a strong parliament, the Seym. At the time, the Polish(-Lithuanian) Commonwealth became the biggest state in Europe covering the territories of present-day Poland, Lithuania, Ukraine, Latvia, Estonia, and Belarus. The Seym issued numerous regulations that began to change and unify the dissimilar, historical, regional, economic institutions across this vast country. In the mid-seventeenth century, a constitutional conflict over the mode of royal election led to the introduction of the liberum veto - the right of a single delegate to discontinue the Seym's proceedings and nullify its decisions. The veto was used to prevent any further constitutional change. Moreover, by bribing the 
delegates to the parliament, Prussia, Austria, and Russia made frequent use of the veto to abort the Seym's sessions and weaken the Polish state. This led to a lack of effective law-making at the central level of the state (all of this will be discussed later in detail). This "historical experiment" offers a rare opportunity to test if legal capacity and regulatory output of central institutions of governance stimulated pre-1800 market integration. Relying on the research of successful historical England/Britain and the Dutch Republic is insufficient to falsify the hypothesis that strong parliamentary regimes promoted markets.

In this article, I use the historical record to understand how the gradual weakening of the Polish state between the formation of the country's parliamentary system in 1505 to the first partition of the country by its neighbours in 1772 affected the integration of the domestic rye market. I link the relevant literature on state capacity, parliamentarism, and market integration. I propose a conceptual framework of the relationships between fragmentation, centralisation, and market integration, based on Stephen Epstein's (2001) earlier formulation. Epstein provided empirical support for his claim that political centralisation fostered commodity market integration with a study of price volatility. I provide further backing for this hypothesis with a comprehensive study of price convergence. To my knowledge, I am the first to identify a correlation between proxies of legal capacity of central state institutions and grain market integration for as early as the pre-industrial period and trace the relationship for nearly three centuries.

Jan Luiten van Zanden, Eltjo Buringh, and Maarten Bosker (2012) proposed to proxy the involvement of an early modern parliament by counting how many days it was in session each year. I present new data on the number of days the Polish Diet was in session each year. I complement this measure of legal capacity with an innovative new index of the Seym's regulatory output based on an original study of its acts. I show that the right of individual delegates to abort the Seym's sessions led to a lack of effective law-making. I demonstrate, that the use of vetoes was not driven by the market conditions but linked to the conflict over the mode of royal election. I discuss via which historical mechanisms, when active, the Diet and its regulations promoted market integration and how its inactivity rose the exchange costs. With the use of regression analysis, I identify that both (1) the number of days the Seym was in session and (2) its regulatory output stimulated price convergence. Moreover, I study the individual impact of various types of regulation. I provide evidence that the Seym, when active, lowered the exchange costs on the market by harmonising taxes and measures. Conversely, I identify that lack of parliamentary activity induced market disintegration. 


\section{THEORETICAL FRAMEWORK}

Various studies measured the extent of market integration in preindustrial Europe (e.g., Bateman 2011; Chilosi et al. 2013; Chilosi, Schulze, and Volckart 2018; Frederico 2012; Malinowski 2016a; Shiue and Keller 2007). The results yield that, after a period of medieval disintegration, markets only became effectively integrated in the nineteenth century. However, the literature also identifies that there were numerous incidents of greater integration that, due to the lack of significant changes in the modes of land transportation in the early-modern era, cannot be simply explained by technological advancements. This suggests institutions played a crucial role in the process of pre-industrial market integration (Uebele 2013). In this article, I use the Polish case to argue that high legal capacity and regulatory activity of a territorial parliament promoted intra-regional domestic commodity market integration.

\section{Conceptual Framework}

In Early Modern Europe, the formation of territorial states gradually replaced the feudal, medieval, political fragmentation with the centralisation of authority defined here as the power to give orders, make decisions, and enforce obedience by the central government. The government consolidated the power that used to be held by regional lords and assemblies which led to an increase in taxation and top-down regulation. The central authority had not yet been divided between executive, legislative, and judiciary branches; instead, the power was shared between kings and parliaments and its balance determined whether regimes were more absolutist or parliamentary. The rise of state capacity of the early modern states has been demonstrated by Kıvanç Karaman and Şevket Pamuk (2010) and recently discussed in detail by Noel Johnson and Mark Koyama (2017).

Did this progressing centralisation and increase in state capacity result in the formation of more integrated domestic markets? According to Epstein (2001, p. 30), "the principal reason why pre-modern (...) productivity experienced frequent setbacks, was the high level of transaction costs in pre-modern societies due to political fragmentation, coordination failures, and upheaval and warfare." Epstein (2001, p. 32) argued that "state formation lowered pre-existing seigniorial dues, overcame co-ordination failures (prisoners' dilemmas) between rival feudal and urban monopolies, systematized legal codes, weights and measures, and reduced the ruler's opportunities and incentives to act autocratically as a 
'stationary bandit' against his subjects. State formation was thus a major cause - possibly the major cause - of market integration and Smithian growth." In the same vein, according to Stephen Broadberry and John Wallis (2017), the creation of uniform impersonal rules by the state was essential for market development. Conversely, weak central authority transferred the power to the local elites who benefited from institutional differences and personalised privileges. Similarly, Johnson and Koyama (2017) argued that centralised and strong governments of early modern France and Prussia managed to suppress the attempts by local elites to extract rents by which they decreased exchange costs on the domestic market. The negative effects of tax predation and political fragmentation were identified by Mark Dincecco (2010). Conversely, David Chilosi, Max Schulze, and Oliver Volckart (2018) demonstrated that the semicentralised Holy Roman Empire promoted capital market integration better than more fragmented Italian polities.

The literature advocates that parliamentary regimes that constrained the executive but still provided order are superior to those that left the King unconstrained. According to Douglass North and Barry Weingast (1989), the Glorious Revolution in England (1688) limited the extractive potential of the rulers and fostered protection of property rights that inspired investment and innovation (see also Van Zanden, Buringh, and Bosker 2012). The authors see impersonal market institutions as a necessary condition for economic development (North and Weingast 1989, p. 831). Daron Acemoglu and James Robinson (2012) argued that parliamentary regimes are generally better at forming inclusive economic institutions. Furthermore, David Stasavage (2011) demonstrated that parliamentary control led to an increase in fiscal capacity of the state that allowed for better provision of public goods, while Dan Bogart (2011) identified that parliamentary supervision encouraged investment in infrastructure that arguably stimulated the development of integrated domestic markets. Lastly, Besley and Persson (2011) argued that institutions of governance can influence the economy only if they have the legal and fiscal capacity to act. Differences in the degree of state capacity and interest of the elites may therefore partially explain why certain parliamentary regimes managed to integrate their domestic market and promote growth while others did not (see Johnson and Koyama 2017).

The idea that the centralisation of power around a parliament should lead to economic development has been criticised, among other reasons, because a parliament could be used to create extractive rents for the elite (Barro 1997; Bogart and Richardson 2011; North, Wallis, and Weingast 2009; Ogilvie and Carus 2014). Moreover, it has been argued 
that political and institutional fragmentation provided economic actors with exit options and therefore forced competition between different institutional technologies that fostered their development (compare Tilly 1990; Cox 2017). In sum, it has not been determined whether fragmentation/centralisation lowered or increased the exchange costs. This article furthers this debate with an empirical investigation.

\section{Transaction Costs in Domestic Grain Market}

Table 1 lists a selection of factors influencing the exchange costs on intra-regional domestic grain market (see Van Tielhof 2002 and Epstein 2001 for similar attempts to model the exchange costs). The selection has two purposes. First, it clarifies how high legal capacity of central state institutions promoted market integration. This effort is based on Epstein's (2001) model of the feudal economy (term coined by the author). Table 1 lists the general theoretical mechanisms proposed by Epstein (2001). I discuss specific historical examples of these mechanisms in a subsequent section. Second, Table 1 also lists a selection of other factors affecting commodity market integration based on the relevant literature (e.g., Bochove 2008; Malinowski 2016a; Rybarski 2015; Van Tielhof 2002). The selection will motivate the inclusion of control variables into the subsequent empirical models.

Following the convention, exchange costs are arbitrarily divided into (1) transportation costs, such as costs relating to physically moving the goods, and (2) transaction costs, that is, costs of organising the exchange. Additionally, Table 1 also lists the factors that affect the nominal cost of exchange due to changes in (3) the value of the means of exchange. Specifically, these are the changes to the (a) purchasing power (e.g., inflation) and (b) the silver content of the currency. I divide the factors affecting the costs into five main groups: fixed, exogenous, marketdriven, resulting from the high legal capacity of central state institutions, and resulting from their low capacity. These first three groups of factors motivate the choice of the control variables in the subsequent empirical analysis. The last two groups are the focus of this article and are based on Epstein (2001). Needless to say, this simple model does not account for all possible determinants of exchange costs due to the complexity of this core issue in the economics literature (e.g., Greif 2000).

Regarding the fixed factors, I distinguish between (1) the physical distance that a good had to be moved and (2) differences/similarities in languages and culture between localities that either facilitated or hampered the exchange. Regarding the exogenous factors, I highlight 
TABLE 1

SELECTED FACTORS INFLUENCING THE EXCHANGE COSTS ON THE INTRA-REGIONAL DOMESTIC GRAIN MARKET

\begin{tabular}{|c|c|c|c|}
\hline $\begin{array}{l}\text { Types of Factors } \\
\text { Influencing } \\
\text { Exchange Costs }\end{array}$ & Transportation Costs & Transaction Costs & $\begin{array}{l}\text { Value of } \\
\text { Currency }\end{array}$ \\
\hline Fixed & Distance & $\begin{array}{l}\text { Differences in } \\
\text { language and } \\
\text { culture }\end{array}$ & \\
\hline Exogenous & $\begin{array}{l}\text { Climate/weather; } \\
\text { Interstate warfare }\end{array}$ & & \\
\hline Market forces & $\begin{array}{c}\text { Wages; } \\
\text { Cost of capital goods }\end{array}$ & $\begin{array}{l}\text { Interest rates; } \\
\text { Storage }\end{array}$ & Purchasing power \\
\hline $\begin{array}{l}\text { High legal } \\
\text { capacity of central } \\
\text { state institutions } \\
\text { (factors that lower } \\
\text { the costs) }\end{array}$ & $\begin{array}{l}\text { State monopoly on } \\
\text { tariffs (e.g., tolls); } \\
\text { Safer trade routes; } \\
\text { Trade access and } \\
\text { well-maintained } \\
\text { infrastructure }\end{array}$ & $\begin{array}{c}\text { Standardized } \\
\text { measures and } \\
\text { moneys; } \\
\text { Uniform taxation; } \\
\text { Inter-regional } \\
\text { contract enforcement; } \\
\text { Uniform regulations }\end{array}$ & $\begin{array}{l}\text { More stable silver } \\
\text { content of the } \\
\text { currency }\end{array}$ \\
\hline $\begin{array}{l}\text { Low legal } \\
\text { capacity of central } \\
\text { state institutions, } \\
\text { fragmentation, and } \\
\text { rent-seeking by } \\
\text { regional elites } \\
\text { (factors that } \\
\text { increase the costs) }\end{array}$ & $\begin{array}{l}\text { Unconstrained and } \\
\text { privately-collected } \\
\text { tariffs (e.g., tolls); } \\
\text { Domestic armed } \\
\text { conflict }\end{array}$ & $\begin{array}{c}\text { Maintaining } \\
\text { dissimilar and } \\
\text { traditional measures } \\
\text { and moneys; } \\
\text { Dissimilar and } \\
\text { fragmented taxation; } \\
\text { Risk of predation } \\
\text { by the local elite; } \\
\text { Personal privileges for the } \\
\text { local elite }\end{array}$ & $\begin{array}{l}\text { Declining silver } \\
\text { content of the } \\
\text { currency }\end{array}$ \\
\hline
\end{tabular}

Source: See the text.

the importance of (3) climate and weather conditions that, among others, affected the agricultural output/economies of scale and the quality of the trade routes (e.g., prevalence of mud or snow) and (4) interstate warfare. For simplicity, I arbitrarily assume that, especially in the short term, the likelihood of a country being involved in a trade-disrupting, interstate, military conflict was independent of the country's legal and fiscal capacity but driven by exogenous international politics (compare Tilly 1990). ${ }^{1}$

\footnotetext{
${ }^{1}$ Most wars fought by Poland were an extension of foreign dynastic politics and were related to succession crises (see Gierowski 2001). Moreover, in general, the Polish nobility believed that low military spending would discourage a preventive invasion (Bardach 1957). However, it was the period of weaker capacity in the seventeenth and eighteenth centuries that featured the most destructive attacks. Similarly, higher state capacity in the sixteenth century was also associated with frequent military campaigns (see the Online Appendix). In sum, both weak and strong capacity coincided with interstate warfare. The assumption of exogeneity of the interstate warfare is a strong one. To relax this assumption, in a robustness test, I limit the sample to the years of peace.
} 
Regarding the market forces, I build on the general factors discussed by Milja van Tielhof (2002) and Christiaan van Bochove (2008) in their respective studies of the grain trade. In particular, I assume that transportation costs mainly depended on the (5) wages that were paid to the people who handled the grain and the (6) costs of capital goods such as the cart, raft, or horses used in transportation. ${ }^{2}$ Moreover, transaction costs were influenced by the (7) cost of obtaining credit and the (8) cost of storage. ${ }^{3}$ Lastly, the value of the currency was influenced by (9) its purchasing power (for discussion see Van Tielhof 2002).

The last two groups of factors concern the role of centralisation/fragmentation and state capacity. Based on North (1981), Epstein (2001) argued that the exchange costs were a function of the clarity of the "rulesof-the-game." Ineffective central governance shifted the power to the regional level and promoted feudal-type jurisdictional fragmentation that encouraged regional rent-seeking and institutional differentiation. According to Epstein (2001, p. 32), "the cost of trade was defined mainly by institutional regulation and tariffs." Regarding transportation costs, the high legal capacity of central state institutions lowered the exchange costs by monopolising the right to collect tariffs. This opposed the incentive of regional landowning elites, for example, to introduce tolls on their private land. Moreover, according to Epstein, strong central institutions promoted and provided safety on roads. First, by raising taxation and empowering officials, the state defended the merchants against bandits. Second, by introducing order and clear relations of power, the state prevented armed domestic conflict between regional (war)lords that plighted the medieval period. Third, having an overarching perspective on the domestic trade-network, the central state institutions supported development of intra-regional trade infrastructure (e.g., building bridges and establishing trade roads) that could not be accomplished by individual regional elites constrained by their regional interest and jurisdiction (see a subsequent section for specific examples of the aforementioned types of policies).

Lastly, according to Epstein, active central state institutions lowered the transaction costs by unifying the tax codes and measures. A single currency backed by a strong centralised state countered the monetary confusion caused by different regions pursuing independent monetary policies and using different coins. Moreover, Epstein argued that

\footnotetext{
${ }^{2}$ I assume stable or no monetary costs of feeding the draft animals because these can be fed from the transported grain.

${ }^{3}$ North and Weingast (1989) argued that interest rates proxy the quality of institutions. Epstein (2000) demonstrated that the rates formed irrespectively of the type of governance. For simplicity, I assume that, in the short term, the costs of borrowing were driven by the supply of and demand for capital.
} 
centralisation promoted the protection of property rights and contract enforcement across regions; while jurisdictional fragmentation increased the scope of discrimination or exclusion of foreigners when enforcing inter-regional contracts, uniform judiciary systems of a strong centralised state promoted equality against the law (see the next section for specific examples). The high legal capacity of the state also arguably supported the courts' effectiveness (compare Besley and Persson 2011). Furthermore, fragmentation enabled regional elites to use their local influence to create rents and obtain personal privileges. In Poland, the strengthening of serfdom in the seventeenth and eighteenth century, that is, the lack of legal protection of the peasants by the state against the landlords that resulted in higher rents, is a classical example of this process (Malinowski 2016b).

\section{THE CASE OF OLD POLAND}

Until 1572, Poland was ruled by hereditary kings. Already in the late middle ages, the prerogatives of the King were gradually limited by a range of privileges given to the nobility, Szlachta, the political ancestors of feudal knights who accounted for around 10 percent of the population (Jędruch 1998, p. 24). In 1355 and 1374, Kings Kazimierz and Louis the Hungarian promised not to levy any new taxes without the nobility's consent. This resulted in the creation of only marginal permanent taxes; it also inspired the development of regional representative bodies, Dietines, known as Seymiks, originally assembling to give the required consent to taxation. These evolved into institutions of direct democracy, albeit with no universal franchise, where all male adult nobles who were willing to participate met to make decisions regarding their lands by majority voting. After 1454, when issuing any new laws, not only imposing taxes, kings had to consult the Dietines (Bardach 1957).

The increasingly federal character of the state and the privileges given to the nobility led to the formation of the Seym, to which, from 1468 onwards, the Dietines elected delegates. The oldest historical record of the Seym, composed of the hereditary King, the appointive Senate and elective House of Delegates, dates back to 1493. After 1505, no law binding the whole country could be passed without the explicit unanimous approval of the three parts of the Seym. It marked the formation of the system of Estate Monarchy, not dissimilar to the one built around the Parliament in England, the Estates General in France, the Cortes in Spain, and the Riksdag in Sweden, with the difference that in many other European countries the rulers retained some legal autonomy and 
could issue, for example, edicts without the need of the assemblies to legalize all their initiatives. In Poland, the King could only propose and veto legislation. Because he could not rule by decree, the ruler needed the Diet, of which he was an integral part, to exercise influence. The bills agreed on by the House of Delegates and Senate became legal acts only after the King gave the royal assent to all of them jointly at the end of the Seym's session. If a session of the Seym ended prematurely, it automatically failed to produce any legally binding acts. Laws agreed on by the Seym were valid on the local level, however, the principal of regional self-governance allowed the Seymiks to issue their own bylaws next to the central laws. When the Seym was inactive, the Seymiks were the only authorities that could create laws, albeit, only on the local level.

In 1573, amid a succession crisis, it was decided that each new King of Poland (who was also a Grand Duke of Lithuania) would be elected in a universal election by all the Szlachta; any domestic or foreign nobleman could be elected. This effectively abolished hereditary successions in Poland and turned the Estate Monarchy into a Republic with the elective kings serving as a lifelong chief magistrate. Upon the elections, every new King had to agree to a set of basic principles known as the Cardinal Laws or Golden Liberties that were effectively, avant la lettre, the constitution of the Republic. They stipulated that the King would: (1) respect all the privileges given to the nobility, (2) summon the Seym regularly, (3) be constantly audited by the representatives of the Senate, and (4) be abolished should he fail to observe the laws of the Republic and threaten the freedom of the nobility. These constitutional provisions were effective - the Seym was summoned regularly and King Jan Kazimierz, who wanted to strengthen the royal authority, was forced to abdicate in 1668.

Van Zanden, Buringh, and Bosker (2012) proposed to proxy the involvement of an early modern parliament by counting how many days it was in session each year (see also Hoppit 2017, pp. 46-50). ${ }^{4}$ The authors used this method to study the British Parliament. In the context of most Western European countries that retained the power of the rulers to perform some forms of legal actions independently, parliamentary activity captures the bargaining between the ruler and his subjects. However, in the Polish context where the King, Senate, and House of Delegates were

\footnotetext{
${ }^{4}$ Van Zanden, Buringh, and Bosker (2012) also constructed indexes of activity based on how often a parliament met each century. They set the Polish index at zero because they argued, after Marongiu (1968, p. 88), that the Seym did not meet their definition of a parliament, which was only valid if it represented the cities. As the cities were represented in the Seym, for discussion see Jędruch (1998, p. 90), the values for Poland should be revised. A revised index would be 78/82, 41/59, and 17/39 meetings (only concluding/all) in the sixteenth, seventeenth, and eighteenth centuries, respectively.
} 

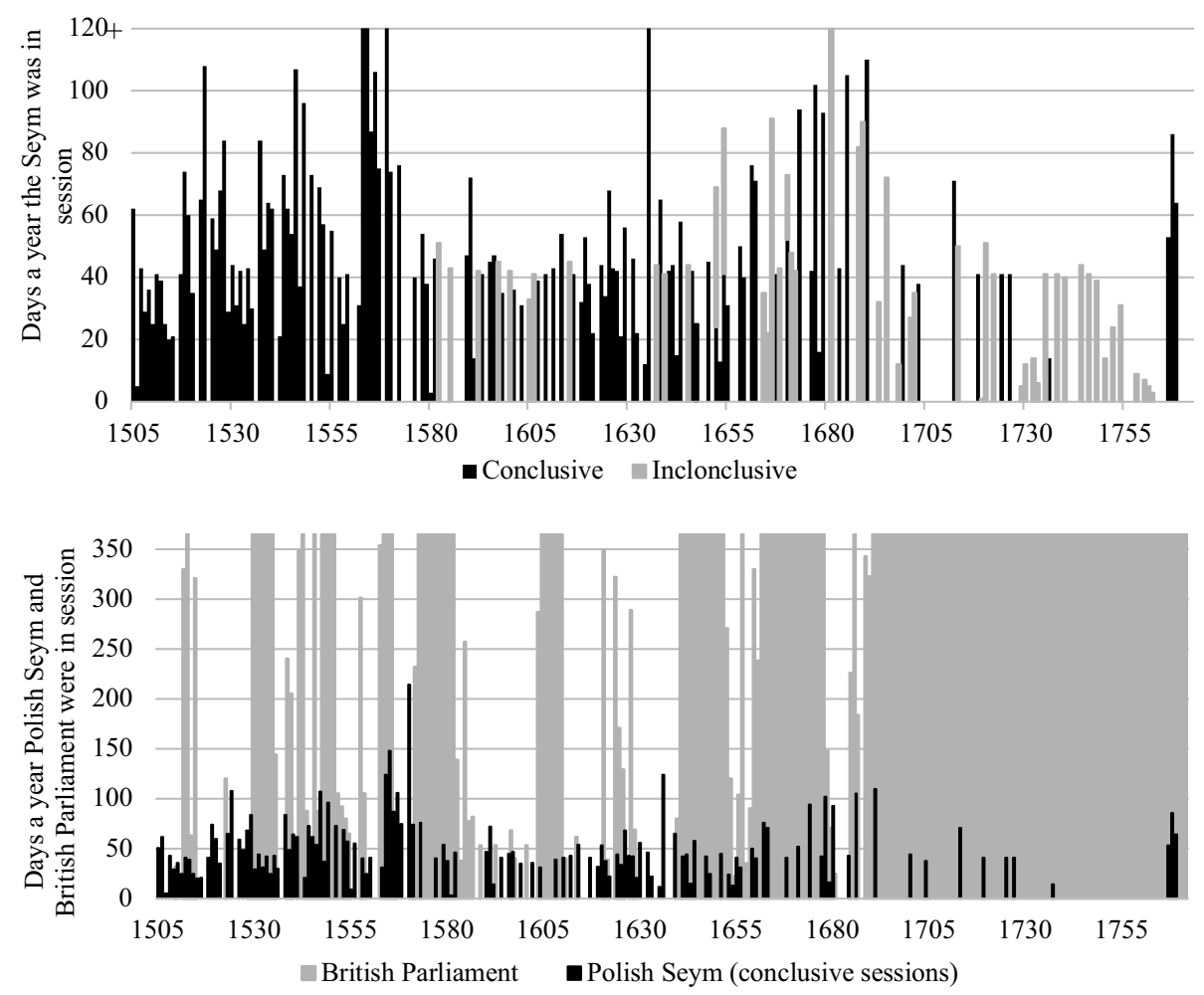

FIGURE 1

NUMBER OF DAYS A YEAR POLISH SEYM AND BRITISH PARLIAMENT WERE IN SESSION, 1505-1772

Source: Poland: Konopczyński (1948). The author reported the date of the opening and closing of each individual session of the Seym. Sessions related to royal election procedure are not included. Britain: Van Zanden, Buringh, and Bosker 2012. See the Online Appendix.

complementaries, parliamentary activity represents the state's capacity to take legal action. Figure 1 shows new data on the number of days between the opening and closing of the Seym's sessions each year. It distinguishes between the conclusive sessions that produced acts and the ones that were discontinued before the royal assent.

Figure 1 demonstrates that the sixteenth century was the golden age of Polish parliamentarism. At the time of the formation of the parliamentary system, the Seym's operations were frequent and conclusive. However, even then the British Parliament was visibly more active. On the other hand, after the second half of the seventeenth century, most of the sessions of the Seym become inconclusive. Conversely, in the eighteenth century, the British Parliament was permanently in session. This inaction of the Seym was a result of the introduction of the rule of unanimity of the decisions of the House of Delegates. 
This legal change in the operation of the Seym was a result of a major constitutional crisis. In the mid-seventeenth century, Poland was struggling with a Kozak uprising, a war with Russia, a Swedish invasion, and Turkish incursions. To ensure more political stability, the progressive party associated with the King, and dominated by the midincome nobility, proposed that the new kings would be elected before the death of the incumbent. This inspired opposition of the conservatives, primarily the magnates and their clients, who saw the proposal as a threat to the Golden Liberties. To block the possibility of a constitutional change, they insisted on the right of a single deputy to discontinue the parliamentary proceedings before the royal assent and effectively nullify its decisions-liberum veto. The first use of this practice took place in 1652 and inspired major political and constitutional conflict between the conservative republicans and progressive royalists that escalated into a civil war in 1663 . The conflict ended with the victory of the conservative faction, abdication of the King, and the introduction of the liberum veto into the Cardinal Laws in 1669. The liberum veto was used both by Polish conservatives who wanted to prevent the constitutional change and by the foreign agents that bribed the delegates to the Seym to weaken the Polish state. For example, in the period 1697 to 1763, 28 sessions were terminated. Prussia and France were credited with having caused seven disruptions each, while Russia sponsored 11 vetoes (Jędruch 1998, p. 156). Termination of the session was therefore largely unrelated to domestic market conditions but was driven by politics.

To illustrate this point, Figure 2 shows that there was no correlation between the duration of the Seym's sessions and the average contemporaneous silver price of rye - an indicator of the market conditions. Moreover, there was no correlation between the duration of the Seym's sessions and the contemporaneous (same year) rye price gaps - an indicator of the exchange costs (see the Online Appendix). ${ }^{5}$ Furthermore, the left panel of Figure 2 also plots the price of grain in the years the sessions were aborted. The results indicate that the sessions were discontinued at any price level. This is confirmed by a binary logistic (logit) regression that does not identify a relationship between the rye price (or the size of the price gap) and the chance of the veto being used (see the Online Appendix).

The use of the veto was linked to the constitutional conflict. To demonstrate this, I constructed a royal tenure index ranging from zero in the year the King was elected to 100 in the year he died. For each year, the index

\footnotetext{
${ }^{5}$ Note that the subsequent empirical analysis identifies a relationship between the duration of the Seym's sessions at time $t-1$ and lower rye price gaps at time $t$.
} 

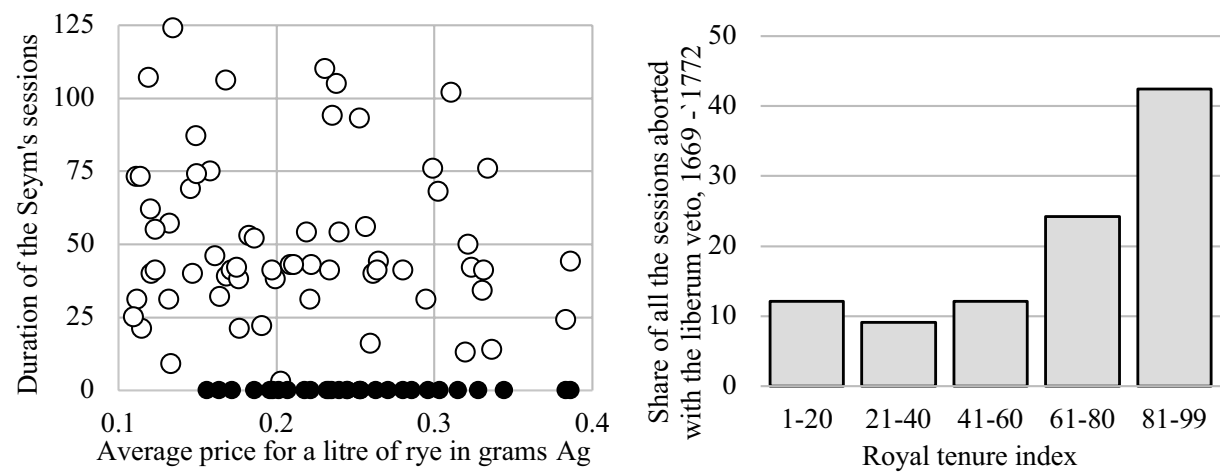

ODays the Seym was in session that concluded

- Aborted sessions

FIGURE 2

(LEFT) RELATIONSHIP BETWEEN THE AVERAGE PRICE OF RYE AND THE CONTEMPORANEOUS DURATION OF PARLIAMENTARY SESSIONS; (RIGHT) DISTRIBUTION OF ABORTED SESSIONS BY THE VALUE OF THE ROYAL TENURE INDEX

Source: The royal tenure index excludes the years of both death (100) and election (0). See the Online Appendix. Based on silver rye prices in Cracow, Gdańsk, Lviv, Lublin, and Warsaw (Malinowski 2016a).

equals the ratio of the number of years the King had already been in the office to the total duration of his entire reign (times 100). For example, for the third year of a ten-year reign (from election till death), the index is 30 . I assume that all the relevant actors could predict each King's demise due to, for example, visible aging, disease, or likely abdication. Approaching elections rekindled the constitutional conflict and provoked the veto. The right panel of Figure 2 plots the distribution of all the vetoes and yields that they occurred more often when the royal tenure index was high. A binary logistic (logit) regression identifies that an increase in the index by one point was associated with a significant increase in the chance of the veto being used (see the Online Appendix). In the Online Appendix, I use the royal tenure index to successfully instrument parliamentary activity (compare Jones and Olken 2005).

The inability of the parliament to conclude many of its sessions led to the failure of the government. The King could not, as it was to a varying degree in the case in the absolutist countries, serve justice, rule by decree, or collect new unauthorised taxes. This resulted in the decline in both the legal and fiscal capacity of the state. Figure 3 denotes revenue of the central government in a range of countries and depicts that, after the sixteenth century, Poland not only began to lag behind other European states that were becoming increasingly centralised but also collected fewer funds in absolute terms. 


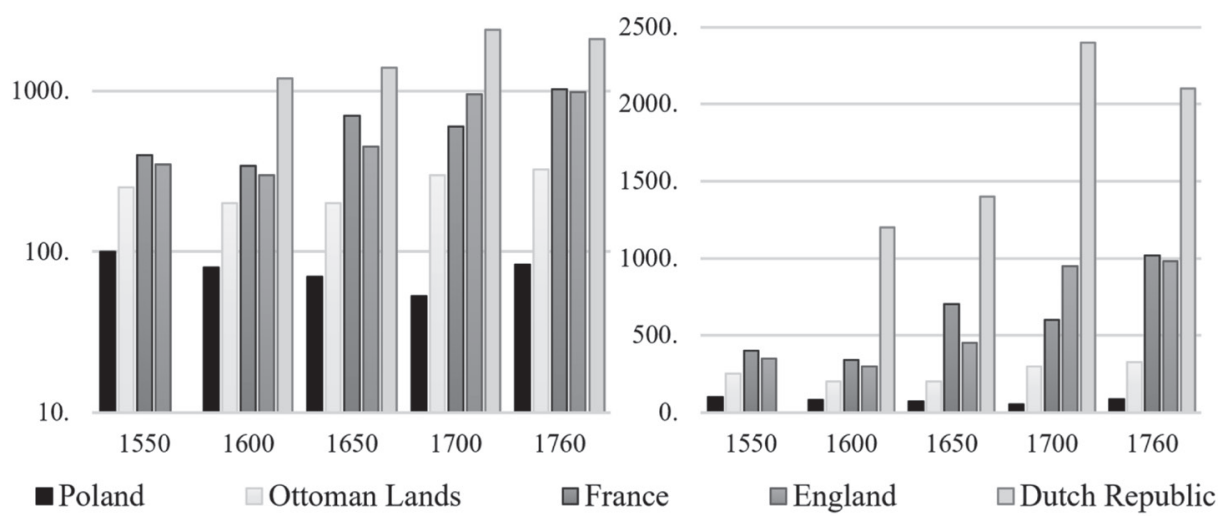

FIGURE 3

THE FISCAL CAPACITY OF THE POLISH STATE IN A EUROPEAN PERSPECTIVE, CENTRAL STATE REVENUE PER CAPITA, LOGARITHMIC AND LINEAR SCALE, CENTIGRAMS OF SILVER, 1550-1760

Source: Values for Poland in 1600, 1650, 1700, and 1760 see the Online Appendix. Values for Poland in 1550 and as well as other countries were taken from Karaman and Pamuk (2010).

The weakening of the Seym resulted in a shift of power from the central to the regional level that retained its effective means of independent self-governance. By 1600, there were 74 of these regional assemblies in the country representing 118 lands and counties (Jędruch 1998, p. 26). Seymiks served as regional courts, and in times of no effective central leadership, regulated the economic policy of their lands. Because, the Seymiks were typically dominated by unchallenged local magnates, the shift of power to the local level effectively resulted in re-feudalisation (Bardach 1957).

\section{REGULATORY ACTIVITY OF THE SEYM}

How did the Seym impact the exchange costs outlined in Table 1? When the Diet was in session it was responsible for serving justice, enforcing existing laws, and constructing new ones. The index of parliamentary activity from Figure 1 represents the potential to pass new acts and the degree as to which the state was able to serve justice and enforce laws (legal capacity). The Seym was the highest court in the country monitoring the state's officials and other powerful individuals. ${ }^{6}$ Moreover, it elected parliamentary commissioners that travelled around the country to enforce the Seym's regulations, such as the toll sizes. These courts

\footnotetext{
${ }^{6}$ Next to the Seym there was also the Tribunal, that is, an appeal court in cases concerning the nobility.
} 
and commissioners were only active when the parliament was in session (Rybarski 1939). Therefore, in principle, longer sessions potentially enforced the laws better. Conversely, termination of its sessions upset the operations of the court and the commissioners.

To demonstrate the impact of the Seym on institutional harmonisation, I complement the index of legal capacity (Figure 1), with an original measure of the Seym's regulatory output. I investigate the acts of the Seym from 1505 to 1772 published in their compilation (Ohryzko 1859-1889). I am interested in the laws that were relevant to the economy. I group the regulations imposed by the Seym into eight areas of regulatory activity that stand out in the source material, that is, laws regulating, unifying, standardising, and/or promoting: (1) uniform taxation, (2) tolls, (3) trade infrastructure, (4) measures, (5) trade access, (6) monetary policy, (7) contract enforcement, and (8) courts' operations. I study only the impersonal laws that applied across the country. I do not analyse laws that gave personal, city-specific, or regional privileges. The details regarding the creation of the underlying dataset are available in the Online Appendix. The index of regulatory output ranges from zero, that is, no regulatory activity, to potentially eight - the Seym's acts regulating at least one aspect of all the above-mentioned areas (the maximum historical value of the index for Poland is seven).

Figure 4 shows the index of regulatory output. It depicts the regulatory crisis since the late seventeenth century and the revival of the Seym in the 1760s. The index correlates well with the index of parliamentary activity/ legal capacity in Figure 1. The Pearson's correlation coefficient of the two indexes is 0.52 . This is mostly because the Seym could not create new laws when it was not in session or when the session was aborted. The index of regulatory output is heterogeneous. For clarification, I discuss individual areas of regulatory activity and provide examples of specific regulations.

\section{Uniform Taxation}

The Seym was of paramount importance for developing a coherent tax policy as it was originally formed to consent to any new taxation. Poland was a domain state with marginal permanent taxes (FilipczakKocur 1995). For this reason, to ensure a stable influx of funds, taxes had to be agreed on repeatedly. Each concluding Seym issued a general tax, uniwersat poborowy, which set general tax rates. In the years when the uniwersał was not published, the King had to approach every Seymik independently to validate the central tax. Different levels of taxation 


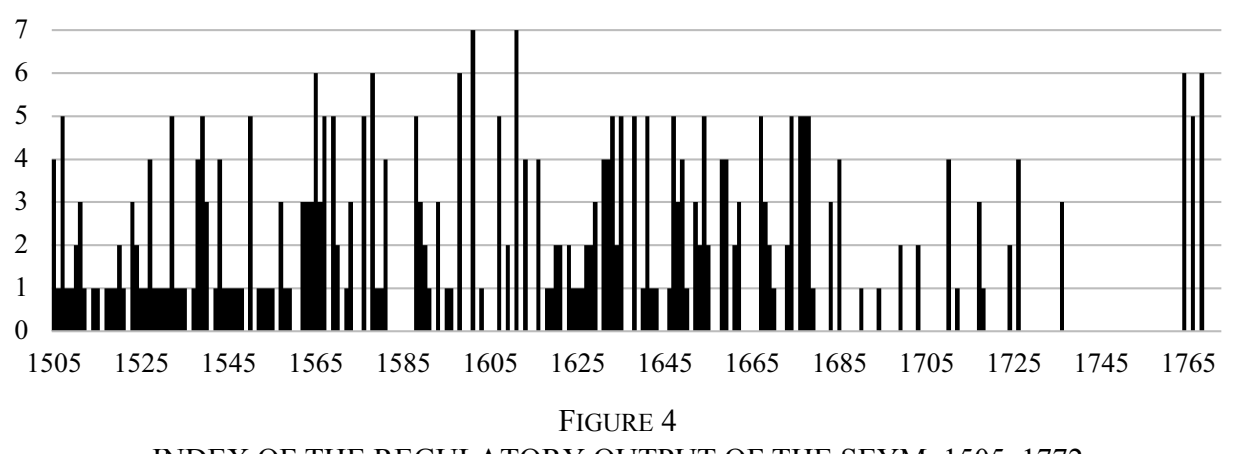

INDEX OF THE REGULATORY OUTPUT OF THE SEYM, 1505-1772

Source: See the Online Appendix.

between the lands accepting and refusing the tax increased the exchange costs (the public goods problem). Conversely, publishing the uniwersat instantly (next year when the tax was enacted) promoted similar taxation and market integration.

\section{Regulation of Toll Collection}

Since 1576, the King was not allowed to levy and regulate tolls without the Seym's consent. When the parliament was active, it frequently issued laws stipulating the punishments for the illegal collection of private tolls (acts of 1589, 1601, 1607) and regulated the exact procedure of farming the relevant incomes (acts of 1538, 1569, 1589, 1736). Furthermore, in 1601, the Seym regulated how people can appeal unjust collected tolls. The lack of parliamentary regulation resulted in less control over tax farmers and encouraged local landlords to create illegal private tolls.

\section{Safer Roads and Better Trade Infrastructure}

The Seym secured the roads by issuing regulation. For example, the acts of 1507 and 1609 instructed the local officials to protect merchants travelling on the official trade routes and punish the criminals who disturbed them. The Seym also commissioned bridges (e.g., acts of 1633 and 1635) and promoted maintenance of roads. For example, in 1539, it instructed that the trade roads had to be clear and wide enough to fit carts and oxen. Moreover, in 1576, to increase access, the Seym stipulated that people travelling to reach a market or a main road via private land could not be stopped or charged a fee.

However, the Seym also set trade routes to the advantage of individual cities. The Diet repeatedly confirmed these privileges (e.g., act of 1649). 
The laws also stipulated that it was illegal to use roads other than the official trade routes (e.g., act of 1712). This limited freedom; however, clearly defined trade routes arguably allowed the state's officials to protect them.

\section{Standardization of Measures}

The Seym repeatedly instructed the lands to standardise measures (e.g., acts of 1550, 1565, 1588, 1598, 1601, 1611, 1616, 1631, and 1635). In 1764, on a wave of political reforms, a parliamentary act ordered unification of all the measures in the country. These central regulations were gradually implemented locally. A bylaw passed by the Seymik of the Land of Dobrzyn offers a convenient demonstration:

Korzec [the tool used to measure the volume of grain] has to be just. [...] Korzec in all towns of the Land of Dobrzyn, i.e. Dobrzyn, Lipń, Bobrowniki, Niesząw, Skąpe, Rypno, Gorzno, has to be as instructed by the parliamentary act of His Majesty the King so that there would be the same measures throughout. (Kluczycki 1887, p. 29)

These regulations had an effect. Stanisław Mielczarski (1962) studied sizes of the korzec in Poland in the sixteenth century; according to his findings, the country was divided into several trade regions using the same measures of volume. Mielczarski demonstrated that, at the time of high parliamentary activity, these regions broadened thus making the economy more institutionally integrated. The repetition of the acts instructing the lands to standardise the measures is indicative of their incomplete implementation. Nonetheless, the acts incentivised standardisation that was not stimulated otherwise.

\section{Access to the Grain Trade}

The landed nobility needed to sell its agricultural produce. It wanted the grain to easily reach ports and cities. Nobles believed it was below their social standing to physically engage in the trade themselves. To allow the others to move the grain for them, the policies of the Seym consistently supported the free movement of grain (Rybarski 2015). For example, in 1567, the Seym declared the freedom of trade, that is, that everyone had a right to trade in every commodity that was already on the territory of the country. In 1576, the Seym prohibited trade monopolies and instructed the King to protect the freedom of the commodity market. In 1565 , foreign merchants were granted the protection of the state. This furthered the access. 
TABLE 2

GRADUAL COLLAPSE AND A BRIEF RECOVERY OF THE POLISH EARLY MODERN MONETARY SYSTEM

\begin{tabular}{|c|c|c|c|c|c|}
\hline King & $\begin{array}{c}\text { No. of } \\
\text { Polish Mints } \\
\text { During } \\
\text { Reign }\end{array}$ & $\begin{array}{l}\text { Average } \\
\text { Silver } \\
\text { Content of } \\
\text { One Grosz } \\
\text { During } \\
\text { Reign }\end{array}$ & $\begin{array}{l}\text { Average } \\
\text { Silver } \\
\text { Content of } \\
\text { One English } \\
\text { Pence } \\
\text { During } \\
\text { Reign }\end{array}$ & $\begin{array}{l}\text { Dates of } \\
\text { Polish } \\
\text { Monetary } \\
\text { Reforms }\end{array}$ & $\begin{array}{l}\text { No. of } \\
\text { Different Types } \\
\text { of Legal Coins } \\
\text { According to } \\
\text { the Reforms }\end{array}$ \\
\hline $\begin{array}{l}\text { Zygmunt I } \\
(1506-1548)\end{array}$ & 6 & $0.99 \mathrm{~g}$ & $0.62 \mathrm{~g}$ & 1521,1535 & 10 \\
\hline $\begin{array}{l}\text { Stefan Batory } \\
(1576-1586)\end{array}$ & 8 & $0.89 \mathrm{~g}$ & $0.48 \mathrm{~g}$ & 1580 & 10 \\
\hline $\begin{array}{l}\text { Zygmunt III } \\
(1587-1632)\end{array}$ & 17 & $0.42 \mathrm{~g}$ & $0.46 \mathrm{~g}$ & 1623 & 21 \\
\hline $\begin{array}{l}\text { Jan Kazimierz } \\
(1648-1668)\end{array}$ & 14 & $0.34 \mathrm{~g}$ & $0.46 \mathrm{~g}$ & 1650 & 14 \\
\hline $\begin{array}{l}\text { August III } \\
(1733-1763)\end{array}$ & $\begin{array}{l}\text { Minted in } \\
\text { Saxony }\end{array}$ & $0.13 \mathrm{~g}$ & $0.46 \mathrm{~g}$ & 1736 & 16 \\
\hline $\begin{array}{l}\text { Stanisław } \\
\text { August } \\
(1764-1795)\end{array}$ & 2 & $0.12 \mathrm{~g}$ & $0.46 \mathrm{~g}$ & 1766 & 11 \\
\hline
\end{tabular}

Source: Dylewski 2012; Hoszowski 1928, 1934; Allen 2001.

\section{Effective Monetary Policy}

The King was not allowed to issue coin without the Seym's approval. The Seym regulated (a) the official exchange rate between silver and gold, (b) the use of foreign currency (e.g., acts of 1588, 1598, 1601, 1620, and 1628), and (c) the standard of the Polish coins (e.g., acts of 1564, 1567, and 1569). Table 2 presents the development of the monetary system. Minting privileges were given to individual masters who were expected to hold to the Seym's instructions rather than free-ride on the system by putting less metal into coins than indicated by the official seigniorage. They faced the prisoner dilemma problem, as they did not know if the other mints were also going to uphold the regulations. The silver value of the coins was the highest in the early sixteenth century. Polish financial historians identified examples of manipulations of the silver content to the benefit of the mint-masters in the seventeenth century. For example, according to Adam Dylewski (2012), the Seym was too weak to discipline the free-riders and the increase in the number of mints can be interpreted as a sign of handing away rents/personal privileges. The crisis escalated during the personal union with Saxony in the first half of the eighteenth 
century, when it was decided that Polish money would be minted abroad, in other words, outside the Seym's control.

Table 2 shows that the silver content of the currency in Poland dropped much more significantly than in England/Britain that enjoyed a more active Diet. This supports Van Zanden, Buringh, and Bosker's (2012) claim that active parliaments promoted more stable currencies. Moreover, the sixteenth century was the period which had the least variation in types of monies, which meant that the policymakers kept the system relatively simple and transparent. The increase in the number of different types of monies in the seventeenth century shows the difficulties with balancing the vested interest of different lands eager to use their historical coins (Dylewski 2012). The issue of the monetary confusion was successfully addressed by the Seym only during its brief revival in the 1760 s.

\section{Contract Enforcement and "Courts' Operations"}

Regarding "contract enforcement," among others, the Seym regulated creditor-lender relations. For example, in 1505, it stipulated that debt obligations without a written contract could be nullified with a testimony. This encouraged formalisation of contracts. In 1540, the Seym decided that merchants had a right to demand repayment of the debts from the nobility. This furthered the equality against the law. In 1543, it stipulated that the debtor cannot postpone repayment of the debt longer than a day in case of a small sum and six weeks in case of a large one. This clarified the exact obligations. Regarding "courts' operations," the Seym regulated the functioning of the courts and selection of the judges. Without regulation, these policies gravitated towards dissimilar local customs.

\section{METHODOLOGY AND SOURCES}

Building on the established literature, I assume that markets become more integrated if the exchange costs decrease and prices converge (see Federico 2012). I link the process to the, so-called, law-of-one-price that states that price in location $i$ is equal or lower than the price in location $j$ plus the cost of trade between locations $i$ and $j$. The law-of-one-price is demonstrated by Equation (1).

$$
P_{i-j}=\mid \text { Price }_{i, t}-\text { Price }_{j, t} \mid \leq \text { Exchange_costs }_{i-j, t}
$$

The law states that any rise in the price gap $P$ between cities $i$ and $j$ above the exchange costs is expected to have been diminished by an instant arbitrage 
performed by the grain merchants (Van Bochove 2008; Federico 2012; Malinowski 2016a). A decrease in the price gap is associated with a decline in the trade costs between the two cities. While price convergence signifies integration, an increase in the price gap should proxy fragmentation (see previous studies that used this intuition in Federico 2012). Using the law as the workhorse of the analysis, I test the hypothesis that legal capacity and regulatory output of the Seym influenced the integration of the domestic market with the use of the regression analysis. Building directly on the law-of-one-price, I analyse absolute silver price gaps between different city pairs (compare Persson 2004). I investigate rye, the most traded grain with an unregulated price on the market (Wyczański 1969).

The price gap data is based on annual silver prices of 100 litres of rye in six Polish cities: Gdańsk, Warsaw, Cracow, Lublin, Lviv, and Koenigsberg (15 city pairs). I also use a control group of four cities located in The Holy Roman Empire of the German Nation: Augsburg, Leipzig, Munich, and Breslau (6 city pairs). These foreign cities were not affected by the Seym but shared similar climatic conditions with the neighbouring Polish cities. Moreover, they were exposed to the same pan-European trends in prices. The price data has been taken from compilations of price and wage data made by Mikołaj Malinowski (2016a; 2016c) and Robert Allen (2001). The information about the dataset is available in the Online Appendix.

Figure 5 presents the long-term correlation between the development of the average silver rye price gap between Polish cities (see the Online Appendix) and the index of parliamentary activity. It shows that the price gaps formed a new higher level during the period of Seym's inaction. Figure 5 yields that the exchange costs were about 40 percentage points lower when the Seym was more active.

To diagnose as to what extent the Seym's operations correlated with changes in the price gap, I estimate three linear regression equations based on three empirical strategies: (a) a difference-in-difference, (b) a study of annual levels, and (c) an analysis of year-on-year changes - first differences. Equation (2) employs the difference-in-difference method. It analyses both Poland and the Empire that shared similar climate and geographical location but followed different trajectories of political development. The Holy Roman Empire was a confederation; The Golden Bull of 1356 cemented the largely independent rule of the dukes over their respective territories and limited the authority of the Emperor. Moreover, the Imperial Diet, Reichstag, was formed in the late fifteenth century and, initially, it had a relatively limited impact on the Empire. However, in 1648, The Peace of Westphalia bound the Emperor to accept all decisions made by the Reichstag. Armed with this prerogative, the Imperial Diet 


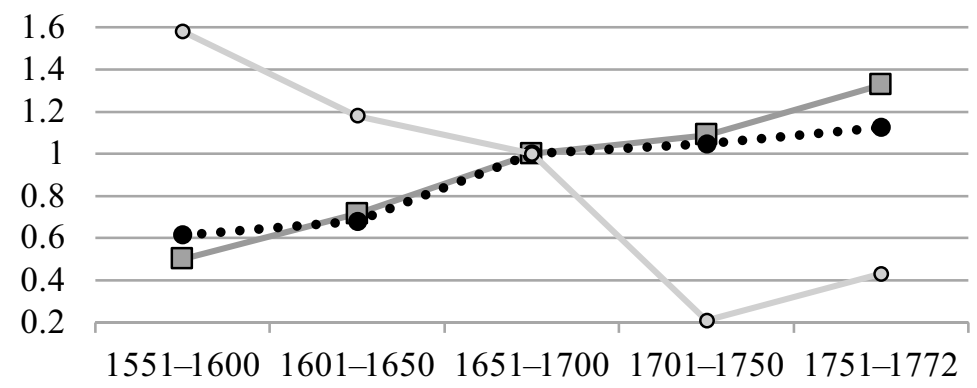

$\square$ Average price gap $\quad \cdots \bullet$ PPP average price gap

- Parliamentary activity

FIGURE 5

LONG-TERM CORRELATION OF THE AVERAGE RYE PRICE GAP AND

PARLIAMENTARY ACTIVITY IN POLAND

Source: Indexed values. Based on silver rye prices in Cracow, Gdańsk, Lviv, Lublin, and Warsaw (Malinowski 2016a). Purchasing Power Parity (PPP) obtained by dividing the average silver price gap by a consumer price index based on the bare-bones basket (Malinowski 2016c). Parliamentary activity based on Figure 1 .

was permanently in session from 1663 until 1806, that is, the dissolution of the Empire. This signified a relative increase in centralisation. The impact of the Empire on market integration has been recently analysed by Chilosi, Schulze, and Volckart (2018).

Equation (2) features three types of differences: (a) the difference in rye price gaps between pairs of either strictly Imperial or Polish cities, (b) the difference in rye price gaps before and after the 1660s, that is, the introduction of the liberum veto in 1669 and the beginning of Reichstag's supremacy in 1663, and (c) the difference-in-difference. Since opposite political changes happened at the same time in Poland and The Holy Roman Empire, the difference-in-difference captures the market effect of the Seym's failure to act vis-à-vis both (1) its own past good performance and (2) the contemporaneous straightening of the Reichstag. Therefore, the difference-in-difference measures the average effect of the gap in legal capacity between the failed Seym and the successful Reichstag on the exchange costs. If identified it proves the studied effect of parliamentary (in)action on market integration (see the Online Appendix for the discussion of the parallel trends assumption). Equation (2) is

$$
\begin{gathered}
L_{i-j, t}=\alpha+\beta_{1} P O L_{i-j}+\beta_{2} P O S T_{-} 1660 s_{t} \\
+\beta_{3} P O L_{-} P O S T_{-} 1660 s_{i-j, t}+\sum_{m=4}^{8} \beta_{m} C_{i-j, t} \\
+\sum_{n=9}^{14} \beta_{n} D_{t}+\sum_{o=15}^{35} \beta_{o} \theta_{i-j}+\beta_{36} \delta_{t}+\varepsilon_{i-j, t},
\end{gathered}
$$


where $\alpha$ is the intercept, $i-j$ indicates a pair of cities $i$ and $j, t$ indicates year, $\operatorname{Ln} P_{i-j, t}$ the natural logarithm of the absolute silver price gap between a pair of cities $i-j$ in year $t$. I use the logarithm to mitigate the effect of outliers. $P O L_{i-j}$ is a dummy variable equal one if both $i$ and $j$ are located in Poland and zero if they are located in the Empire (there are no international pairs); POST_1660s $s_{t}$ is a dummy variable equal to one if $t$ is after 1669 and zero if it is before 1660 (the 1660s are excluded from the analysis); POL_POST_1660s $s_{i-j, t}$ is a dummy variable equal to one for the records concerning Polish price gaps observed after the 1660s and zero otherwise; $C_{i-j, t}$ are control variables; $D_{t}$ are time-period dummies/ fixed effects; $\theta_{i-j}$ are city-pair dummies/fixed effects (one Polish and one Imperial pair are dropped to avoid collinearity); $\delta_{t}$ is the annual time trend; and $\varepsilon$ the error-term. The time-period dummies differentiate between six sub-periods: 1505-1550, 1551-1600, .. 1751-1772 (the first period is dropped to avoid collinearity). The control variables stem from the discussion of the factors relevant for the exchange costs identified in Table 1, that is, distance, differences in language and culture, warfare, climate, wages, cost of capital goods, interest rates, storage, and purchasing power of the currency. City-pair dummies/fixed effects $\theta_{i-j}$ account for the fixed factors, that is, distance and differences in language and culture. The control variables $C_{i-j, t}$ account for all the exogenous and market factors listed in Table 1. These are: (1) warfare proxied by the number of people killed in military conflicts (data from Brecke 2012, see the Online Appendix); (2) climate proxied by the difference to the long-term mean temperature (data from Büntgen et al. 2013, same for the Empire and Poland); (3) wages proxied by the average daily silver wage of unskilled labourers (Malinowski 2016c; Allen 2001); (4) interest rates proxied by the rates of return on investment (that also captures the cost of capital goods and storage, see McCloskey and Nash 1984 on the relationship between interest rates and storage; data from Hoszowski 1928, 1934; Chilosi, Schulze, and Volckart 2018; Huang, Chilosi, and Sapoznik 2019); and (5) purchasing power of the currency proxied by the average consumer price index (hereafter CPI, based on the "respectability basket" featuring bread not rye; data from Allen 2001). Factors pertaining to the change in the legal capacity of the central state institutions are captured by POLAND_POST_1660s. Equations (2) to (4) do not account for the silver value of the currency due to its dependence on state capacity that may result in collinearity (see Table 1; changes in the silver value are accounted for in a robustness test). Because the inactivity of the Seym after 1669 should have increased the exchange costs, the hypothesis is that $\beta_{3}$ is positive and statistically significant. 
Equation (3) complements the difference-in-difference specification. It uses the annual measures of the Seym's legal capacity and regulatory output. It replaces the difference-in-difference approach with the interaction-term approach. Equation (3) studies the annual levels of either legal capacity or regulatory output. The logic of the model is that the Seym's actions should only have had an impact on transaction costs within Poland and not in the Empire. To capture this, I interact the measures of the Seym's activity with the POL dummy. Equation (3) is

$$
\begin{gathered}
\operatorname{Ln} P_{i-j, t}=\alpha+\gamma_{1} S_{t-1}+\gamma_{2} S_{t-1} * P O L_{i-j}+\gamma_{3} P O L_{i-j} \\
+\sum_{m=4}^{8} \gamma_{m} C_{i-j, t}+\sum_{n=9}^{14} \gamma_{n} D_{t}+\sum_{o=15}^{35} \gamma_{o} \theta_{i-j}+\gamma_{36} \delta_{t}+\varepsilon_{i-j, t},
\end{gathered}
$$

where the variable of interest $S_{t-1}$ is either the legal capacity (Figure 1), that is, parliamentary activity denoted as the number of days the Seym was in session that concluded, or the regulatory output representing the number of areas of economic activity that were regulated in new acts (Figure 4). As regulatory output is a form of parliamentary activity they are never estimated in the same equation. Equally, because the grain prices come mostly from the first quarter of the year (Adamczyk 1935), so before any session would conclude, and because parliamentary acts needed to be printed, distributed and acknowledged by the Dietines before they could be implemented, Equation (3) looks at the lag of $S$. Because the higher activity of the Seym should have lowered the exchange costs, the hypothesis is that $\gamma_{2}$ is negative and statistically significant.

Grain prices are typically autocorrelated. This can be mitigated by differencing the data (Van Bochove 2008). A pooled-OLS regression of $\operatorname{Ln} P_{i-j, t}$ on $\operatorname{Ln} P_{i-j, t-1}$ identifies serial autocorrelation (regressions based on all 21 city pairs, P-value 0.00). For this reason, Equation (4) employs first differences. It models what drove the year-on-year changes in price gaps. The model assumes that the change in the price gap between $t-1$ and $t$ was dependent on Seym's action at time $t-1$ and changes in: war intensity, wages, temperature, interest rates, and the CPI. As a robustness, I test if substitution of $S_{t-1}$ with $\Delta S_{t-1}$ affects the results. Equation (4) is

$$
\begin{gathered}
\Delta L n P_{i-j, t}=\alpha+\varphi_{1} S_{t-1}+\varphi_{1} S_{t-1} * P O L_{i-j} \\
+\sum_{m=4}^{8} \varphi_{m} \Delta C_{i-j, t}+\varepsilon_{i-j, t^{*}}
\end{gathered}
$$

This equation is used to study either both the Imperial and Polish or only the Polish city pairs. As in the case of Equation (3), $S_{t-1}$ is proxied by 
TABLE 3

DESCRIPTIVE STATISTICS OF THE USED DATA

\begin{tabular}{|c|c|c|c|c|c|c|}
\hline & \multicolumn{3}{|c|}{$\begin{array}{l}\text { Levels; } \\
\text { All } 21 \text { Pairs }\end{array}$} & \multicolumn{3}{|c|}{$\begin{array}{c}\text { First Differences; } \\
\text { Three Main Polish Pairs }\end{array}$} \\
\hline & $\mathrm{N}$ & Mean & SD & $\mathrm{N}$ & Mean & SD \\
\hline Ln price gap & 1645 & 3.09 & 1.64 & 144 & 0.1 & 0.57 \\
\hline $\begin{array}{l}\text { Parliamentary } \\
\text { activity (lag) }\end{array}$ & 1645 & 18.48 & 32.39 & 144 & $\begin{array}{c}13.66 \\
\text { (level) }\end{array}$ & $\begin{array}{r}28.59 \\
\text { (level) }\end{array}$ \\
\hline $\begin{array}{l}\text { Regulatory output } \\
\text { (lag) }\end{array}$ & 1645 & 1.46 & 2.51 & 144 & $\begin{array}{r}1.16 \\
\text { (level) }\end{array}$ & $\begin{array}{r}2.27 \\
\text { (level) }\end{array}$ \\
\hline War casualties & 1645 & 29.14 & 53.23 & 144 & -1.59 & 36.46 \\
\hline Interest rates & 1645 & 5.28 & 0.94 & 144 & -0.02 & 0.39 \\
\hline Temperature & 1645 & -1.12 & 0.94 & 144 & 0.02 & 0.88 \\
\hline Wage & 1645 & 1.66 & 0.58 & 144 & -0.01 & 0.14 \\
\hline
\end{tabular}

Source: Malinowski (2019).

either (a) parliamentary activity/legal capacity or (b) regulatory output. I also proxy $S_{t-1}$ with (c) a set of eight dummy variables each capturing the effect of regulating one specific area of regulatory activity (see the Online Appendix). This is estimated by analysing all eight areas both jointly (one regression) and separately (eight regressions). When studying individual regulations, to avoid having to include multiple interaction terms, the sample will be restricted to Poland.

To ensure that price gaps are independent, I analyse only pairs that do not share a city. For Poland, the main sample of three independent city pairs is Gdańsk-Cracow, Koenigsberg-Lviv, and Warsaw-Lublin. For the Empire, the selected pairs are Munich-Augsburg and Breslau-Leipzig. I choose these pairs because together they have the highest number of data points. For robustness, I study all the city pairs (1) jointly, (2) separately, and (3) look at different combinations of independent city pairs (see the Online Appendix). The standard errors are clustered around both the city pairs and individual years. Table 3 yields the descriptive statistics of the used data.

\section{RESULTS OF THE EMPIRICAL ANALYSIS}

\section{Difference-in-Difference and Annual Levels Specifications (Equations (2) and (3))}

Table 4 shows the results of the analysis of pairs of both Polish and Imperial cities based on Equations (2) and (3). Specifications I to IV show the results of estimation of Equation (2). The interaction term Poland 
TABLE 4

RESULTS OF THE REGRESSION ANALYSIS BASED ON EQUATIONS (2) AND (3)

\begin{tabular}{|c|c|c|c|c|c|c|c|c|}
\hline & I & II & III & IV & V & VI & VII & VIII \\
\hline Dependent & $\operatorname{Ln} P_{i-j, t}$ & $\operatorname{Ln} P_{i-j, t}$ & $\operatorname{Ln} P_{i-j, t}$ & $\operatorname{Ln} P_{i-j, t}$ & $\operatorname{Ln} P_{i-j, t}$ & $\operatorname{Ln} P_{i-j, t}$ & $\operatorname{Ln} P_{i-j, t}$ & $\operatorname{LnP} P_{i-j, t}$ \\
\hline $\begin{array}{l}\begin{array}{l}\text { Post1660s } \\
\text { (dummy) }\end{array}\end{array}$ & $\begin{array}{l}0.049 \\
(0.47)\end{array}$ & $\begin{array}{l}-0.279 \\
(0.24)\end{array}$ & $\begin{array}{l}0.514^{*} \\
(0.07)\end{array}$ & $\begin{array}{c}-0.534^{* *} \\
(0.04)\end{array}$ & & & & \\
\hline $\begin{array}{l}\text { Poland } \\
\text { (dummy) }\end{array}$ & $\begin{array}{l}2.41 * * * \\
(0.00)\end{array}$ & $\begin{array}{c}0.84^{* * *} \\
(0.00)\end{array}$ & $\begin{array}{l}2.991 * * * \\
(0.00)\end{array}$ & $\begin{array}{c}3.484 * * * \\
(0.00)\end{array}$ & $\begin{array}{c}2.161 * * * \\
(0.00)\end{array}$ & $\begin{array}{c}3.72 * * * \\
(0.00)\end{array}$ & $\begin{array}{c}1.962 * * * \\
(0.00)\end{array}$ & $\begin{array}{c}3.47^{* * *} \\
(0.00)\end{array}$ \\
\hline $\begin{array}{l}\text { Poland post } 1660 \mathrm{~s} \\
\text { (dummy) }\end{array}$ & $\begin{array}{l}0.217^{*} \\
(0.08)\end{array}$ & $\begin{array}{l}0.408^{*} \\
(0.08)\end{array}$ & $\begin{array}{c}1.573^{* * *} \\
(0.00)\end{array}$ & $\begin{array}{c}0.887 * * * \\
(0.00)\end{array}$ & & & & \\
\hline $\begin{array}{l}\text { Parliamentary activity } \\
\text { (lag) }\end{array}$ & & & & & $\begin{array}{c}0.003 * * * \\
(0.00)\end{array}$ & $\begin{array}{l}0.002 \\
(0.16)\end{array}$ & & \\
\hline $\begin{array}{l}\text { Parliamentary activity (lag) * } \\
\text { Poland (dummy) }\end{array}$ & & & & & $\begin{array}{c}-0.008^{* * *} \\
\quad(0.00)\end{array}$ & $\begin{array}{c}-0.007^{* * *} \\
\quad(0.00)\end{array}$ & & \\
\hline $\begin{array}{l}\text { Regulatory output } \\
\text { (lag) }\end{array}$ & & & & & & & $\begin{array}{l}0.004 \\
(0.78)\end{array}$ & $\begin{array}{c}-0.003 \\
(0.88)\end{array}$ \\
\hline $\begin{array}{l}\text { Regulatory output (lag) * } \\
\text { Poland (dummy) }\end{array}$ & & & & & & & $\begin{array}{c}-0.09 * * * \\
(0.00)\end{array}$ & $\begin{array}{c}-0.06^{* *} \\
(0.05)\end{array}$ \\
\hline CPI & & & $\begin{array}{l}0.103 * * * \\
(0.00)\end{array}$ & $\begin{array}{c}0.099 * * * \\
(0.00)\end{array}$ & $\begin{array}{l}0.07 * * \\
(0.02)\end{array}$ & $\begin{array}{c}0.08^{* * *} \\
(0.00)\end{array}$ & $\begin{array}{l}0.06^{* *} \\
(0.03)\end{array}$ & $\begin{array}{c}0.079^{* * *} \\
(0.00)\end{array}$ \\
\hline War casualties & & & $\begin{array}{l}-0.001 \\
(0.46)\end{array}$ & $\begin{array}{c}-0.003 * * * \\
(0.00)\end{array}$ & $\begin{array}{c}0 \\
(0.76)\end{array}$ & $\begin{array}{c}-0.002 * * * \\
\quad(0.00)\end{array}$ & $\begin{array}{c}0 \\
(0.67)\end{array}$ & $\begin{array}{l}-0.002 * * * \\
(0.00)\end{array}$ \\
\hline Temperature & & & $\begin{array}{l}0.028 \\
(0.35)\end{array}$ & $\begin{array}{l}0.036 \\
(0.38)\end{array}$ & $\begin{array}{l}0.025 \\
(0.44)\end{array}$ & $\begin{array}{l}0.032 \\
(0.43)\end{array}$ & $\begin{array}{l}0.025 \\
(0.42)\end{array}$ & $\begin{array}{l}0.035 \\
(0.38)\end{array}$ \\
\hline Interest rates & & & $\begin{array}{l}0.012 \\
(0.88)\end{array}$ & $\begin{array}{c}0.141 \\
(0.2)\end{array}$ & $\begin{array}{l}0.19^{* *} \\
(0.02)\end{array}$ & $\begin{array}{l}0.26^{* *} \\
(0.02)\end{array}$ & $\begin{array}{c}0.231 * * * \\
(0.00)\end{array}$ & $\begin{array}{c}0.287^{* * * *} \\
(0.00)\end{array}$ \\
\hline Wages & & & $\begin{array}{c}0.183^{* *} \\
(0.03)\end{array}$ & $\begin{array}{l}0.083 \\
(0.39)\end{array}$ & $\begin{array}{l}-0.07 \\
(0.46)\end{array}$ & $\begin{array}{l}-0.03 \\
(0.71)\end{array}$ & $\begin{array}{l}-0.073 \\
(0.46)\end{array}$ & $\begin{array}{l}-0.03 \\
(0.69)\end{array}$ \\
\hline Time trend & & & $\begin{array}{l}0.003 \\
(0.46)\end{array}$ & $\begin{array}{l}0.003 \\
(0.29)\end{array}$ & $\begin{array}{l}0.06^{* *} \\
(0.04)\end{array}$ & $\begin{array}{l}0.004 \\
(0.15)\end{array}$ & $\begin{array}{c}0.007^{* *} \\
(0.03)\end{array}$ & $\begin{array}{l}0.004^{*} \\
(0.09)\end{array}$ \\
\hline City-pair fixed effects & No & Yes & Yes & Yes & Yes & Yes & Yes & Yes \\
\hline Time-period fixed effects & No & Yes & Yes & Yes & Yes & Yes & Yes & Yes \\
\hline City-pair clusters & No & Yes & Yes & No & Yes & No & Yes & No \\
\hline Year clusters & No & Yes & Yes & Yes & Yes & Yes & Yes & Yes \\
\hline Sample & $\begin{array}{c}\text { All } 21 \\
\text { pairs and } \\
\text { no } 1660 \text { s }\end{array}$ & $\begin{array}{c}\text { All } 21 \\
\text { pairs and } \\
\text { no } 1660 \mathrm{~s}\end{array}$ & $\begin{array}{c}\text { All } 21 \\
\text { pairs and } \\
\text { no } 1660 \mathrm{~s}\end{array}$ & $\begin{array}{l}5 \text { indep. } \\
\text { pairs and } \\
\text { no } 1660 \text { s }\end{array}$ & $\begin{array}{l}\text { All } 21 \\
\text { pairs }\end{array}$ & $\begin{array}{l}5 \text { indep. } \\
\text { pairs }\end{array}$ & $\begin{array}{l}\text { All } 21 \\
\text { pairs }\end{array}$ & $\begin{array}{l}5 \text { indep. } \\
\text { pairs }\end{array}$ \\
\hline $\mathrm{N}$ & 1,610 & 1,610 & 1,610 & 456 & 1,645 & 509 & 1,645 & 509 \\
\hline $\mathrm{R}^{2}$ & 0.59 & 0.69 & 0.71 & 0.8 & 0.7 & 0.8 & 0.69 & 0.8 \\
\hline
\end{tabular}

$*=$ Significant at the 10 percent level.

$* *=$ Significant at the 5 percent level.

*** $=$ Significant at the 1 percent level.

Notes: OLS regressions. P-values based on heteroscedasticity robust standard errors in brackets. For the selected independent pairs see the text.

Source: See the text.

post 1660s shows the relative impact of the petrification of the Seym by the veto. Specification I analyses all 21 Polish and Imperial city pairs. It does not account for any control variables or city-pair and time-period fixed effects. It identifies that the petrification of the Seym increased the exchange costs. Specifications II and III subsequently incorporate city-pair and time-period fixed effects and the control variables. They 
both identify a strong and statistically significant effect. Specification IV limits the sample to the selected three Polish and two Imperial independent city pairs. This more robust specification identifies a statistically significant effect. This evidence indicates that, in Poland, at the time of state failure, exchange costs were higher and the market was relatively more disintegrated.

Specifications V to VIII analyse the immediate (next year) impact of the Seym's operations on price gaps in Poland and the Empire. Parliamentary activity (lag) * Poland (dummy) captures the impact of the Seym's activity/ legal capacity on Polish domestic rye market. Specification V analyses all 21 Polish and Imperial city pairs. It controls for both city-pair and timeperiod fixed effects, as well as the full set of control variables. It identifies that each additional day the Seym was in an unabridged session had a negative and statistically significant effect on the size of the price gaps. Specification VI analyses the selected three Polish and two Imperial independent city pairs. This more robust specification identifies that the Seym's activity impacted only the city pairs located within Poland. This log-level specification suggests that one additional day in session lowered next year's exchange costs by 0.7 percent. Since the average unabridged session was around 50 days long, a typical concluding Seym lowered the exchange costs by about 35 percent. This broadly corresponds with the difference in the average exchange costs, between periods of an active and inactive Seym, demonstrated in Figure 5. Specifications VII and VIII conduct a corresponding analysis of the regulatory output. They both identify that the regulatory activity was associated with a decline in the exchange costs and that the acts of the Seym impacted only the Polish market. These two log-level specifications suggest that regulation of each additional area lowered the next year exchange costs by 9 or 6 percent, respectively. Since the average session regulated three areas of economic activity, a typical concluding Seym lowered the next year exchange costs by about 27 or 18 percent. These numbers intend to demonstrate the scale of the effect and may over or underestimate the actual values due to, among others, the measurement error. The results of this analysis based on levels identifies that both the Seym's activity/legal capacity and regulatory output had a significant effect on lowering the exchange costs on the Polish rye market.

\section{First Differences (Equation (4)); Individual City Pairs and Specific Areas of Regulation}

Table 5 analyses the year-on-year changes in price gaps. They all control for the full set of control variables. Specification IX analyses all 
TABLE 5

RESULTS OF THE REGRESSION ANALYSIS BASED ON EQUATION (4)

\begin{tabular}{|c|c|c|c|c|c|c|c|c|c|}
\hline & IX & $\mathrm{X}$ & XI & XII & XIII & XIV & $X V$ & XVI & XVII \\
\hline Dependent & $\Delta L n P_{i-j, t}$ & $\Delta \operatorname{Ln} P_{i-j, t}$ & $\Delta L n P_{i-j, t}$ & $\Delta L n P_{i-j, t}$ & $\Delta L n P_{i-j, t}$ & $\Delta L n P_{i-j, t}$ & $\Delta L n P_{i-j, t}$ & $\Delta P_{i} / P_{j_{t}}$ & $\Delta L n P_{i-j, t}$ \\
\hline $\begin{array}{l}\text { Parliamentary } \\
\text { activity (lag) }\end{array}$ & $\begin{array}{l}-0.001 \\
(0.23)\end{array}$ & $\begin{array}{c}-0.006^{* * *} \\
(0.00)\end{array}$ & $\begin{array}{c}-0.005^{* *} \\
(0.05)\end{array}$ & & & $\begin{array}{c}-0.009 * * * \\
(0.00)\end{array}$ & $\begin{array}{c}-0.006^{* * *} \\
(0.00)\end{array}$ & $\begin{array}{c}-0.01 * * \\
(0.05)\end{array}$ & $\begin{array}{c}-0.007 * * * \\
(0.00)\end{array}$ \\
\hline $\begin{array}{l}\text { Parliamentary } \\
\text { activity (lag) * } \\
\text { Poland (dummy) }\end{array}$ & $\begin{array}{c}-0.003^{* *} \\
(0.05)\end{array}$ & & & & & & & & \\
\hline $\begin{array}{l}\text { Regulatory output } \\
\text { (lag) }\end{array}$ & & & & $\begin{array}{c}-0.086^{* * *} \\
(0.00)\end{array}$ & & & & & \\
\hline $\begin{array}{l}\Delta \text { Parliamentary } \\
\text { activity (lag) }\end{array}$ & & & & & $\begin{array}{c}-0.005^{* * * *} \\
(0.00)\end{array}$ & & & & \\
\hline$\Delta \mathrm{CPI}$ & $\begin{array}{l}0.13^{* * *} \\
(0.00)\end{array}$ & $\begin{array}{c}1.66 \\
(0.18)\end{array}$ & $\begin{array}{c}0.67 \\
(0.62)\end{array}$ & $\begin{array}{c}0.666 \\
(0.648)\end{array}$ & $\begin{array}{c}0.489^{* * * *} \\
(0.00)\end{array}$ & $\begin{array}{c}0.15 \\
(0.92)\end{array}$ & $\begin{array}{l}2.265^{*} \\
(0.08)\end{array}$ & $\begin{array}{c}9.41 * * * \\
(0.01)\end{array}$ & $\begin{array}{l}-0.74 \\
(0.67)\end{array}$ \\
\hline$\Delta$ War casualties & $\begin{array}{c}0.001 \\
(0.2)\end{array}$ & $\begin{array}{c}0 \\
(0.52)\end{array}$ & $\begin{array}{c}0 \\
(0.65)\end{array}$ & $\begin{array}{l}-0.001 \\
(0.13)\end{array}$ & $\begin{array}{c}0 \\
(0.49)\end{array}$ & $\begin{array}{c}0 \\
(0.92)\end{array}$ & $\begin{array}{l}0.001 \\
(0.51)\end{array}$ & $\begin{array}{c}0.006 * * * \\
(0.00)\end{array}$ & Omitted \\
\hline$\Delta$ Temperature & $\begin{array}{c}0 \\
(0.97)\end{array}$ & $\begin{array}{c}0.02 \\
(0.55)\end{array}$ & $\begin{array}{l}-0.007 \\
(0.87)\end{array}$ & $\begin{array}{l}0.008 \\
(0.86)\end{array}$ & $\begin{array}{l}-0.02 \\
(0.65)\end{array}$ & $\begin{array}{l}-0.006 \\
(0.89)\end{array}$ & $\begin{array}{l}0.027 \\
(0.7)\end{array}$ & $\begin{array}{l}0.146 \\
(0.28)\end{array}$ & $\begin{array}{l}0.048 \\
(0.34)\end{array}$ \\
\hline$\Delta$ Interest rates & $\begin{array}{c}0.05 \\
(0.63)\end{array}$ & $\begin{array}{l}0.101 \\
(0.32)\end{array}$ & $\begin{array}{l}-0.06 \\
(0.53)\end{array}$ & $\begin{array}{l}-0.08 \\
(0.37)\end{array}$ & $\begin{array}{c}-0.064 \\
(0.5)\end{array}$ & $\begin{array}{l}-0.12 \\
(0.6)\end{array}$ & $\begin{array}{l}0.038 \\
(0.83)\end{array}$ & $\begin{array}{l}0.135 \\
(0.56)\end{array}$ & $\begin{array}{c}-0.37 * * \\
(0.02)\end{array}$ \\
\hline$\Delta$ Wages & $\begin{array}{c}-0.03 \\
(0.9)\end{array}$ & $\begin{array}{c}-0.239 \\
(0.27)\end{array}$ & $\begin{array}{c}-0.008 \\
(0.98)\end{array}$ & $\begin{array}{l}0.118 \\
(0.72)\end{array}$ & $\begin{array}{l}0.031 \\
(0.92)\end{array}$ & $\begin{array}{l}-0.09 \\
(0.81)\end{array}$ & $\begin{array}{l}0.14 \\
(0.5)\end{array}$ & $\begin{array}{c}-2.87 * * * \\
(0.00)\end{array}$ & $\begin{array}{c}0.04 \\
(0.88)\end{array}$ \\
\hline $\begin{array}{l}\Delta \text { Silver content } \\
\text { of the Grosz }\end{array}$ & & & & & & $\begin{array}{l}-7.65 \\
(0.53)\end{array}$ & & & \\
\hline$\Delta$ Grain exports & & & & & & $\begin{array}{l}-0.005 \\
(0.27)\end{array}$ & & & \\
\hline $\begin{array}{l}\text { City-pair clusters } \\
\text { Year clusters }\end{array}$ & $\begin{array}{l}\text { Yes } \\
\text { Yes }\end{array}$ & $\begin{array}{l}\text { Yes } \\
\text { Yes }\end{array}$ & $\begin{array}{l}\text { No } \\
\text { Yes }\end{array}$ & $\begin{array}{l}\text { No } \\
\text { Yes }\end{array}$ & $\begin{array}{l}\text { No } \\
\text { Yes }\end{array}$ & $\begin{array}{l}\text { No } \\
\text { Yes }\end{array}$ & $\begin{array}{l}\text { Yes } \\
\text { Yes }\end{array}$ & $\begin{array}{l}\text { No } \\
\text { Yes }\end{array}$ & $\begin{array}{l}\text { No } \\
\text { Yes }\end{array}$ \\
\hline Sample & $\begin{array}{l}\text { All } 21 \\
\text { pairs }\end{array}$ & $\begin{array}{c}\text { All } 15 \\
\text { Polish } \\
\text { pairs }\end{array}$ & $\begin{array}{c}3 \text { indep. } \\
\text { Polish } \\
\text { pairs }\end{array}$ & $\begin{array}{l}3 \text { indep. } \\
\text { Polish } \\
\text { pairs }\end{array}$ & $\begin{array}{l}3 \text { indep. } \\
\text { Polish } \\
\text { pairs }\end{array}$ & $\begin{array}{l}3 \text { indep. } \\
\text { Polish } \\
\text { pairs }\end{array}$ & $\begin{array}{l}3 \text { indep. } \\
\text { Polish } \\
\text { pairs and } \\
\text { Parl }_{t-1}>0\end{array}$ & $\begin{array}{c}3 \text { indep. } \\
\text { Polish } \\
\text { pairs }\end{array}$ & $\begin{array}{l}3 \text { indep. } \\
\text { Polish } \\
\text { pairs and } \\
\text { no war }\end{array}$ \\
\hline $\mathrm{N}$ & 1,260 & 562 & 144 & 144 & 144 & 144 & 88 & 144 & 85 \\
\hline $\mathrm{R}^{2}$ & 0.06 & 0.08 & 0.1 & 0.07 & 0.11 & 0.11 & 0.08 & 0.12 & 0.17 \\
\hline
\end{tabular}

$*=$ Significant at the 10 percent level.

** = Significant at the 5 percent level.

$* * *=$ Significant at the 1 percent level.

Notes: OLS regressions. P-values based on heteroscedasticity robust standard errors in brackets. For the selected independent pairs see the text.

Source: See the text.

21 Polish and Imperial city pairs. It identifies that each additional day the Seym was in an unabridged session at time $t-1$ lowered the exchange costs between time $t-1$ and $t$, and that the Seym only impacted the exchange costs within Poland.

Thus far all the samples included the control group of Imperial city pairs. All the subsequent specifications focus the analysis on the first differences of the price gaps between the Polish cities. Specifications X and XI analyse the impact of Seym's activity/legal capacity at time $t-1$. 


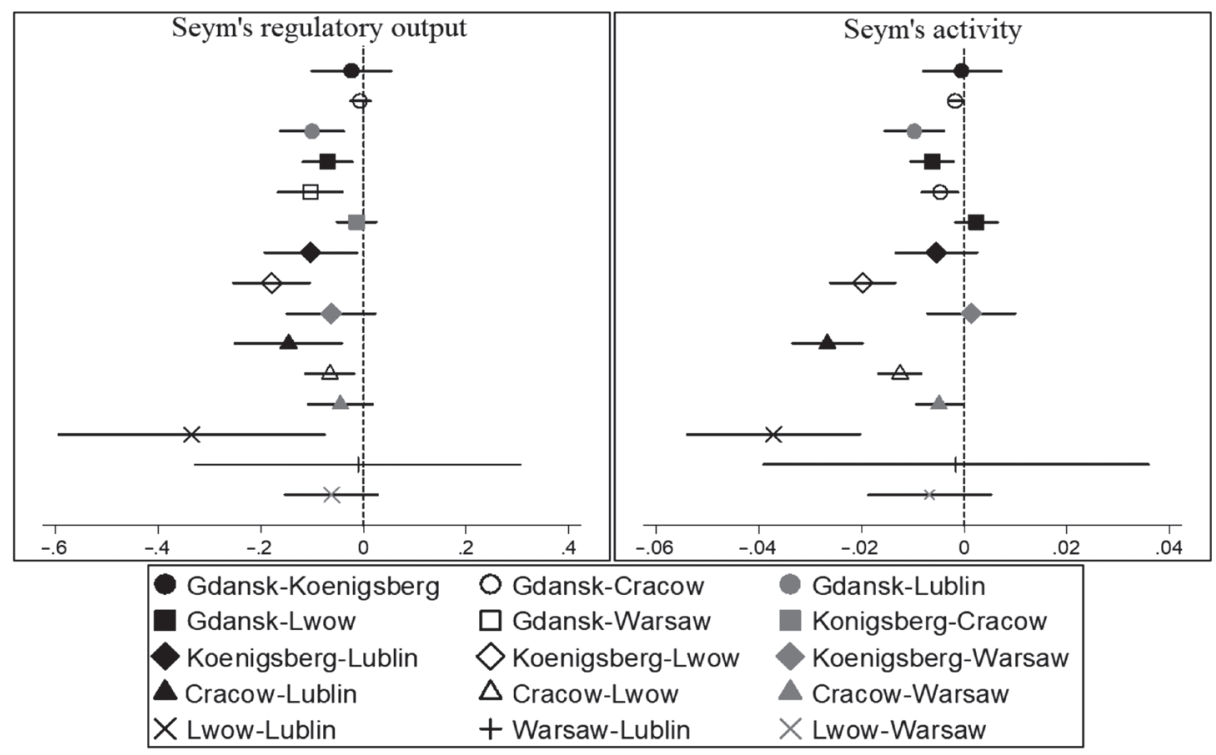

FIGURE 6

CONFIDENCE INTERVALS OF COEFFICIENTS BASED ON THE ANALYSIS

OF THE INDIVIDUAL CITY-PAIR PRICE GAPS WITH EQUATION (4)

Source: See the text.

They analyse all the 15 Polish city pairs and only the three selected independent pairs, respectively. They both identify that each additional day in an unabridged session was associated with a subsequent decline in the exchange costs. The size of the effect is comparable with that identified in Specification VI. Specification XII studies the selected three independent Polish city pairs. It analyses the impact of the Seym's regulatory output and identifies a similar (in size) impact as Specifications VII and VIII that investigate levels.

The results of the analysis based on all the Polish city pairs holds if I exclude, one at a time, each city pair. The results also hold if I analyse different sets of independent city pairs (see the Online Appendix). To demonstrate this point clearly, Figure 6 shows the coefficients of interest obtained from estimation of either the impact of Seym's regulatory output or activity with Equation (4) for each Polish city pair separately (30 regressions). It shows that the relationship between parliamentary activity and regulatory output in the previous year and the year-on-year decline in the exchange costs was consistent across the city pairs. The seemingly unrelated regression procedure identifies that, for both activity and output, these individual coefficients are jointly statistically different to zero (P-value 0.00$)$. 


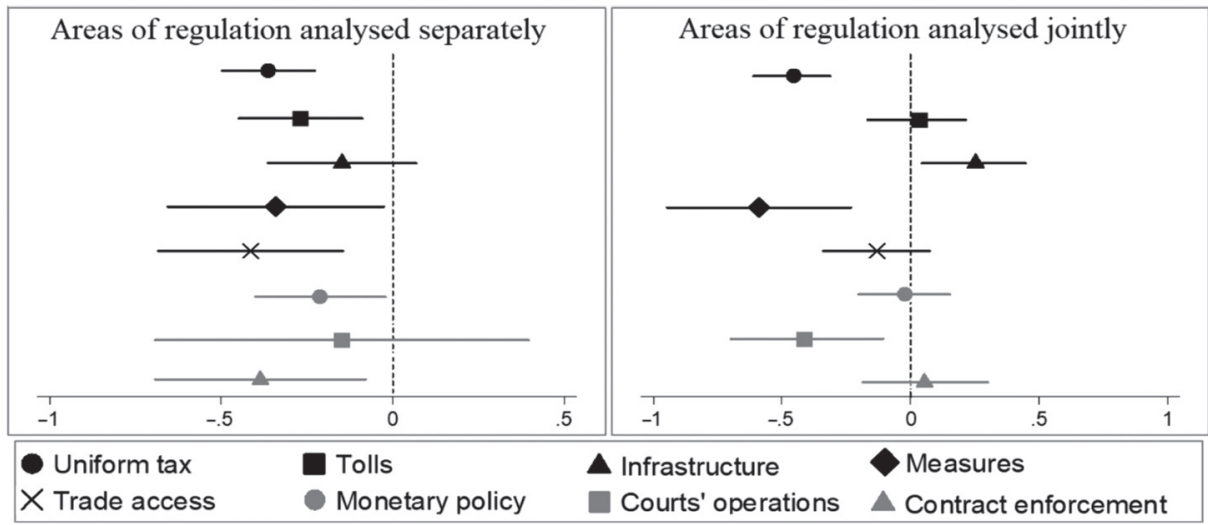

FIGURE 7

CONFIDENCE INTERVALS OF THE IMPACT OF REGULATING EACH OF THE EIGHT INDIVIDUAL AREAS OF REGULATION, ANALYSIS BASED ON THE THREE INDEPENDENT POLISH PRICE-GAP SERIES WITH EQUATION (4)

Source: See the text.

The index of regulatory output groups eight different areas of regulation. I also study the individual impact of regulating each area of regulation. I study eight dummy variables, each equal one if the corresponding area was regulated by at least one new act and zero otherwise (see the Online Appendix). I use Equation (4) to analyse the impact of regulating each area separately (eight regressions). I also analyse the eight series jointly with one regression. I base this analysis on the sample of three independent Polish city pairs. This selection and the first-differences specification combined ensure that the price gap data are independent both across pairs and years.

Figure 7 shows the results of the analysis. The separate one-by-one analysis of the specific areas of regulation (eight regressions) indicates that regulation of all the areas besides infrastructure and court's operations had a statistically significant and negative effect. However, because every concluding session of the Seym issued the general tax, it is useful to disentangle the impacts of different types of regulation. Figure 7 shows the result of a regression specification that accounts for all the types of regulation (one regression). This specification identifies that regulation of the general tax, measures, and court's operations were associated with a decline in the exchange costs on the rye market. The combined evidence from both the separate and joint studies of different regulations suggests that the Polish state supported the formation of an integrated domestic market, at least, by enforcing uniform taxation levels and fostering standardisation of measures. 


\section{Robustness Tests}

Specifications XIII to XVII in Table 5 perform several robustness tests. They are based on the first-differences specification and study the three independent Polish city pairs. This ensures that the price gap data are independent both across pairs and years. Specification XIII tests if the substitution of Parliamentary activity (lag) for $\Delta$ Parliamentary activity (lag) affects the results. I identify that a change in the number of days the Seym was in session between $t-2$ and $t-1$ impacted the change in the exchange costs between $t-1$ and $t$. Specification XIV controls for the silver content of the currency and the size of the grain exports. It identifies a statistically significant impact of legal capacity. Specification XV addresses the issue that, due to the long periods of parliamentary inactivity, the Seym's activity was disproportionally often equal to zero. It restricts the sample to the years directly after concluding sessions (the Seym met and concluded at $t-1$ ). It identifies the effect of interest. Specification XVI studies price ratios, an alternative approach to measuring price convergence (e.g., Bateman 2011). It also identifies the effect of interest. Lastly, the war casualties measure does not account for the exact locations of military conflicts that may affect the city pairs differently. To mitigate this problem, Specification XVII narrows the sample to the years that both $t$ and $t-1$ were the years of peace. Additional robustness tests are available in the Online Appendix. This includes a test that accounts for the direction of warfare, as well as a set of 2SLS regressions with the index of royal tenure used as an exogenous instrument. All the results identify that the state failure had a negative effect on market integration while an active parliament fostered the development of an integrated domestic market.

\section{CONCLUSION}

Economic history's literature on the role of the state in the longterm economic development of preindustrial Europe is divided into two opposing streams. The first argues that constraining governments helped avoid harmful predation, while the second demonstrates that strong governments often played a crucial role in setting up institutions crucial for well-operating markets. These two points of view rarely speak to one another. The case of the British Glorious Revolution led to the conventional knowledge that, in principle, constraining the ruler should promote economic growth. The Polish case problematises this by demonstrating that constraining the monarch had negative political and 
economic consequences. The Polish King had too few prerogatives to oppose centrifugal forces and bind the country together in the absence of a well-functioning parliament. The power vacuum was filled by regional lords that effectively divided the country into various zones of influence. Inter alia, the lack of control allowed them to raise tenurial rents and sharpen serfdom in the country. This demonstrates that limiting the King and forming a parliamentary regime was not a sufficient condition to initiate sustainable economic growth; it at least had to be accompanied by mechanisms preventing the regional elites from hijacking the extractive power.

Initially, in the sixteenth century, this was ensured by a central territorial parliament representing the interest of the landed nobility. The Seym favoured the lowering of transaction costs on the grain market to allow the nobility to export the grain cheaply. To this end, the Seym issued numerous regulations that harmonised economic institutions and fostered market integration. However, the constitutional conflict, foreign intervention, and the particular interest of the richest of the nobles, magnates, to ensure their unsupervised regional influence gradually broke the Seym and resulted in political fragmentation (possibly even re-feudalisation) that eventually led to market fragmentation.

Moreover, the findings suggest that the market economy does not form spontaneously but requires state institutions. This article identifies a positive correlation between the legal capacity of the state, regulatory output, and commodity market integration. The causal link between parliamentary operations and formation of a domestic commodity market is supported by (a) Besley and Persson's theory, (b) Epstein's model, (c) the outlined specific historical mechanisms, (d) the expected exogeneity of the past parliamentary operations and the liberum veto, and (e) the implementation of an instrumental variable. If correct, the link has important implications for our understanding of the long-term growth patterns in early modern Europe.

According to the recent GDP figures, Poland experienced economic growth in the sixteenth century, followed by a decline in the seventeenth century and stagnation in the eighteenth century (Malinowski and Van Zanden 2017). This corresponds with the identified trends in political and market development. The link suggests that the crisis of the central state institutions could be one of the causes of the economic decline of the country via its impact on the domestic market. Conversely, England and the Netherlands were the economic winners of the early modern period. According to Dincecco (2009), these economies managed to find the right balance between a limitation on the executive and territorial consolidation which allowed them to reach high levels of fiscal capacity 
of the state. The results of this article suggest that if the fiscal capacity was complemented by the legal one, high governmental involvement in the formation of domestic commodity market might have been one of the reasons of the economic rise of the North Sea Region. Furthermore, the differences in political developments between the East and West of Europe might have contributed to the historical origins of what is known as the Little Divergence in living standards within Europe.

To prove this hypothesis, one would have to develop standardised and comparable proxies of market integration and legal capacity of the state. There have been few attempts to conduct cross-sectional studies of market development across early-modern Europe, but they suffer from the problem of standardisation (Federico 2012). Regarding measuring legal capacity, Van Zanden, Buringh, and Bosker (2012) constructed the index of parliamentary activity for a range of European countries. However, because the power in the West was often exercised by both the ruler and the representative institutions, a coherent picture also requires systematic accounts of the legal action of the rulers, which do not yet exist. Preindustrial Poland, due to the unique complementarity of its political institutions, provides a valuable insight into the relationship between states and markets, but much remains to be done to fully understand the road historical European states took to develop their domestic markets and promote economic growth.

\section{REFERENCES}

Acemoglu, Daron, and James Robinson. Why Nations Fail. New York: Crown Business, 2012.

Adamczyk, Władysław. Ceny w Lublinie. Lviv: Instytut Popierania Polskiej Twórczości Naukowej, 1935.

Allen, Robert. "The Great Divergence in European Wages and Prices from the Middle Ages to the First World War." Explorations in Economic History 38 (2001): 411-47.

Bardach, Juliusz. Historia państwa i prawa Polskiego. Warsaw: PWN, 1957.

Barro, Robert. Determinants of Economic Growth: A Cross-Country Empirical Study. London: MIT Press, 1997.

Bateman, Victoria. "The Evolution of Markets in Early Modern Europe, 1350-1800: A Study of Wheat Prices." Economic History Review 64, no. 2 (2011): 447-71.

Besley, Timothy, and Torsten Persson. Pillars of Prosperity. Princeton: Princeton University Press, 2011.

Bochove, Christiaan V. The Economic Consequences of the Dutch. Amsterdam: Amsterdam University Press, 2008.

Bogart, Dan. "Did the Glorious Revolution Contribute to the Transport Revolution? Evidence from Investment in Roads and Rivers." Economic History Review 64 (2011): 1073-112. 
Bogart, Dan, and Gary Richardson. "Property Rights and Parliament in Industrializing Britain. Journal of Law and Economics 54, no. 2 (2001): 241-74.

Bolt, Jutta, and Jan L. van Zanden. "The Maddison Project." Economic History Review 67, no. 3 (2014): 627-51.

Bonney, Richard. The Rise of the Fiscal State in Europe c.1200-1815. New York: Oxford University Press, 1995.

Brecke, Peter. “Conflict Catalogue.” Peace Science Society conference paper, Savannah, GA, 2012.

Broadberry, Stephen, and John Wallis. "Growing, Shrinking and Long Run Economic Performance.” NBER Working Paper No. 23343, Cambridge, MA, April 2017.

Büntgen, Ulf, Tomáš Kyncl, Christian Ginzler, et al. "Filling the Eastern European Gap in Millennium-Long Temperature." Proceedings of the National Academy of Sciences of the United States of America 110, no. 5 (2013), 1773-8.

Chilosi, David, Tommy Murphy, Roman Studer, et al. "Europe's Many Integrations: Geography and Grain Markets, 1620-1913." Explorations in Economic History 50, no. 1 (2013): 46-68.

Chilosi, David, Max Schulze, and Oliver Volckart. "Benefits of Empire? Capital Market Integration North and South of the Alps, 1350-1800." Journal of Economic History 78, no. 3 (2018): 637-72.

Cox, Gary. "Political Institutions, Economic Liberty, and the Great Divergence." Journal of Economic History 77, no. 3 (2017): 724-55.

Dimitruk, Kara. “'I Intend Therefore to Prorogue': The Effects of Political Conflict and the Glorious Revolution in Parliament, 1660-1702." European Review of Economic History 22, no. 3 (2018): 261-97.

Dincecco, Mark. "Fiscal Eentralization, Limited Government, and Public Revenues in Europe, 1650-1913." Journal of Economic History 69, no. 1 (2009): 48-103.

_. "Fragmented Authority from ancien régime to Modernity: A Quantitative Analysis." Journal of Institutional Economics 6, no. 3 (2010): 305-28.

Dincecco, Mark, and Gabriel Katz. "State Capacity and Long-Run Economic Performance." Economic Journal 126 (2016): 189-218.

Dylewski, Adam. Historia pieniadza na ziemiach polskich. Warszawa: Carta Blanca, 2012.

Epstein, Stephan. Freedom and Growth. The Rise of States and Markets in Europe. London: Routledge, 2000.

- "The Late Medieval Crisis as an 'Integration Crisis'." In Early Modern Capitalism Economic and Social Change in Europe, 1400-1800, edited by Maarten Prak, 23-48. London: Routledge, 2001.

Federico, Giovanni. "How Much Do We Know about Market Integration in Europe?" Economic History Review 65 (2012): 470-97.

Filipczak-Kocur, Anna. "Poland Lithuania Before Partition." In The Rise of the Fiscal State in Europe c.1200-1815, edited by Richard Bonney, Chapter 14. Oxford: Clarendon Press, 1995.

Gierowski, Józef. Rzeczypospolita w dobie złotej wolności. Cracow: Fogra, 2001.

Greif, Avner. "The Fundamental Problem of Exchange: A Research Agenda in Historical Institutional Analysis." European Review of Economic History 4, no. 3 (2000): 251-84.

Hoppit, Julian. Britain's Political Economies: Parliament and Economic Life, 1660 1800. Cambridge: Cambridge University Press, 2017. 
Hoszowski, Stanisław. Ceny we Lwowie w XVI i XVII wieku. Lviv: IPPTN, 1928.

- Ceny we Lwowie w latach 1700-1914. Lviv: IPPTN, 1934.

Huang, Angela; Chilosi, David; Sapoznik, Alexandra (2019): A Source Collection on Urban annuities, 14th-18th centuries. Version: 1. VSWG. Dataset. http://dx.doi. org/10.15456/vswg.2019084.163202

Jędruch, Jacek. Constitutions Elections and Legislature of Poland, 1493-1993. New York: Eij Books, 1998.

Johnson, Noel, and Mark Koyama. "States and Economic Growth: Capacity and Constraints." Explorations in Economic History 64, (2017): 1-20.

Jones, Benjamin, and Benjamin Olken. "Do Leaders Matter? National Leadership and Growth Since World War II." Quarterly Journal of Economics 120, no. 3 (2005): 835-64.

Karaman, Kivinc, and Şevket Pamuk. Ottoman State Finances in European Perspective, 1500-1914. J. Econ. Hist. 70, no. 3 (2010): 593-629.

Kluczycki, Franciszek. Lauda Sejmików Ziemi Dobrzyńskiej. Cracow: Academie Literarum Cracowiensis, 1887.

Konopczyński, Władysław. Chronologia Sejmów polskich. Cracow: Polska Akademia Umiejętności, 1948.

Malinowski, Mikołaj. "Market Conditions in Preindustrial Poland, 1500-1772." Economic History of Developing Regions 31, no. 2 (2016a): 253-76.

. "Serfs and the City: Market Conditions, Surplus Extraction Institutions and Urban Growth in Poland, 1500-1772." European Review of Economic History 20, no. 2 (2016b): 123-46.

_. "Little Divergence Revisited: Polish Living Standards in a European Perspective, 1500-1800.” European Review of Economic History 20, no. 3 (2016c): 345-67.

- "Economic Consequences of State Failure-Legal Capacity, Regulatory Activity, and Market Integration in Poland, 1505-1772." Ann Arbor, MI: Interuniversity Consortium for Political and Social Research [distributor], 2019-01-09. https://doi.org/10.3886/E108021V1

Malinowski, Mikołaj, and Jan L. van Zanden. "Income and Its Distribution in Preindustrial Poland.” Cliometrica 11, no. 3 (2017): 375-404.

Marongiu, Antonio. Medieval Parliaments, a Comparative Study. London: Eyre \& Spottiswoode, 1968.

McCloskey, Donald, and John Nash. "Corn at Interest: The Extent and Cost of Grain Storage in Medieval England.” American Economic Review 74 (1984): 174-87.

Mielczarski, Stanisław. Rynek Zbożowy Na Ziemiach Polskich w Drugiej Polowie XVI i Pierwszej Połowie XVII Wieku. Gdańsk: Gdańskie Towarzystwo Naukowe, 1962.

North, Douglass. Structure and Change in Economic History. New York: Norton, 1981.

- Institutions, Institutional Change, and Economic Performance. Cambridge: Cambridge University Press, 1990.

North, Douglass, John Wallis, and Barry Weingast. Violence and Social Orders: A Conceptual Framework for Interpreting Recorded Human History. Cambridge: Cambridge University Press, 2009.

North, Douglass, and Barry Weingast. "Constitutions and Commitment: The Evolution of Institutions Governing Public Choice in Seventeenth Century England." Journal of Economic History 49, no. 4 (1989): 803-32. 
O'Brien, Patrick. "The Nature and Historical Evolution of an Exceptional Fiscal State and Its Possible Significance for the Precocious Commercialization and Industrialization of the British Economy from Cromwell to Nelson." Economic History Review 64, no. 2 (2011): 408-46.

Ogilvie, Sheilagh, and Andre Carus. "Institutions and Economic Growth in Historical Perspective." In Handbook of Economic Growth, Vol. 2, edited by Philippe Aghion and Steven N. Durlau, 403-513. Burlington: Elsevier Science, 2014.

Ohryzko, Jozafat. Przedruk zbioru praw staraniem XX. Pijarów w Warszawie, od roku 1732 do roku 1782, wydanego, Volumes 1-9. [Petersburg]: Author, 1859-1889.

Persson, K. Gunnar. "Mind the Gap! Transport Costs and Price Convergence in the Nineteenth Century Atlantic Economy." European Review of Economic History 8, no. 2 (2004): 125-47.

Rybarski, Roman. Skarb i pieniadz za Jana Kazimierza, Michała Korybuta i Jana III. Warsaw: TNW, 1939.

- Handel i polityka handlowa Polski w XVI stuleciu. Warsaw: Napoleon V, 2015.

Shiue, Carol, and Wolfgang Keller. "Markets in China and Europe on the Eve of the Industrial Revolution.” American Economic Review 97, no. 4 (2007): 1189-216.

Stasavage, David. States of Credit: Size, Power, and the Development of European Polities. Princeton: Princeton University Press, 2011.

Tielhof, Milja V. The 'Mother of all Trades'. Leiden-Boston-Koln: Brill, 2002.

Tilly, Charles. Coercion, Capital, and European States, AD 990-1990. Oxford: Blackwell, 1990.

Uebele, Martin. "What Drives Commodity Market Integration? Evidence from the 1800s." CESifo Economic Studies 57, no. 2 (2013): 412-42.

Wyczański, Andrzej. Studia nad konsumpcja żywności w Polsce w XVI i pierwszej połowie XVII wieku. Warsaw: PWN, 1969.

Zanden, Jan L.V., Eltjo Buringh, and Maarten Bosker. "The Rise and Decline of European Parliaments, 1188-1789.” Economic History Review 65, no. 3 (2012): 835-61. 